\title{
Stygobitic crustaceans in an anchialine cave with an archeological heritage at Vodeni Rat (Island of Sveti Klement, Hvar, Croatia)
}

\author{
Alessandro Montanari (D) ${ }^{1 *}$, Nicolas Cerveau (D) ${ }^{2}$, Barbara Fiasca (D) ${ }^{3}$, Jean-François \\ Flot (D) ${ }^{4}$, Diana Galassi (D) ${ }^{3}$, Maurizio Mainiero (D) ${ }^{5}$, David McGee (D) ${ }^{6}$, Tadeusz \\ Namiotko (D) ${ }^{7}$, Stefano Recanatini (D) ${ }^{8}$, and Fabio Stoch (D) ${ }^{4}$ \\ ${ }^{1}$ Osservatorio Geologico di Coldigioco, Cda. Coldigioco 4, 62021 Apiro, Italy \\ ${ }^{2}$ Department of Geobiology, Georg-August Universität, Goldschmidtstraße 3, 37077 Göttingen, Germany \\ ${ }^{3}$ Department of Life, Health and Environmental Sciences, University of L'Aquila, Via Vetoio, Coppito, 67100 L'Aquila, Italy \\ ${ }^{4}$ Evolutionary Biology \& Ecology, Université Libre de Bruxelles, C.P. 160/12, Avenue F.D. Roosevelt 50, 1050 Brussels, Belgium \\ ${ }^{5}$ Studio Geologico, Via XXIX Settembre 2/O, 60122 Ancona, Italy \\ ${ }^{6}$ Department of Earth, Atmospheric and Planetary Sciences, Massachusetts Institute of Technology, Cambridge, MA 02142, USA \\ ${ }^{7}$ Department of Genetics and Biosystematics, University of Gdansk, Wita Stwosza 59, 80-308 Gdansk, Poland \\ ${ }^{8}$ Gruppo Speleologico Marchigiano, Via Veneto 10, 60122 Ancona, Italy
}

\begin{abstract}
A group of four amphoras found in the anchialine cave of Vodeni Rat in the Croatian island of Sveti Klement, on a rocky ledge at $24 \mathrm{~m}$ water depth, indicates that a freshwater source was exploited at the bottom of this karstic pit by islanders and/or passing-by sailors from the late Roman Republican Period to the Early Medieval Period. In other words, prior to the $4^{\text {th }}-7^{\text {th }}$ century CE, Vodeni Rat was not an anchialine cave but a Pleistocene karstic pit with a freshwater pool at the bottom. Seawater started to infiltrate this cavity via newly opened fissures in the surrounding limestone after the $4^{\text {th }}-7^{\text {th }}$ century CE, as the archeometric age of the youngest intact amphora found down in the pit suggests. At present, the 29-m-deep water body is stratified, with a saline water layer at the bottom, a freshwater layer at the surface, and a transitional brackish water layer in the middle. Our study of the physical and biological characteristics of the cave water column revealed diversified and highly partitioned populations of stygobitic crustaceans including ostracods, copepods, amphipods, and thermosbaenaceans. Some species known to be exclusively endemic of highly saline habitats were collected from the bottom saline layer, whereas others known to be of freshwater origin were found in the upper water layer. This suggests that the freshwater dwellers were already present in this cave prior to the early medieval event that caused seepage of seawater into this karstic pit.
\end{abstract}

Keywords: Dalmatian underwater speleo-archeology, ostracods, copepods, amphipods, thermosbaenacean Received 30 July 2020; Revised 21 October 2020; Accepted 21 October 2020

Citation: $\quad$ Montanari A., Cerveau N., Fiasca B., Flot J.-F., Galassi D., Mainiero M., McGee D., Namiotko T., Recanatini S. and Stoch F., 2021. Stygobitic crustaceans in an anchialine cave with an archeological heritage at Vodeni Rat (island of Sveti Klement, Hvar, Croatia). International Journal of Speleology, 50 (1), 1-14. Tampa, FL (USA) ISSN 0392-6672

https://doi.org/10.5038/1827-806X.50.1.2342

\section{INTRODUCTION}

An anchialine cave with an archeological heritage

On the steep, treacherous rocky littoral of Vodeni Rat (literally "water cape"), in the little Island of Sveti Klement, the largest of the Pakleni Archipelago that festoons the southwestern offshore of the Island of Hvar, Croatia (Fig. 1), there is a small anchialine cave, with a narrow elliptical entrance at about $12.5 \mathrm{~m}$ above sea level and some $30 \mathrm{~m}$ distance from the sea. An anchialine cave is broadly defined as " $a$ tidally-influenced subterranean estuary located within crevicular and cavernous karst and volcanic terrains that extends inland to the limit of seawater penetration." (Bishop et al., 2015). This type of cave often contains a body of saline water at depth, fresh or brackish water at the surface, and a gradient of increasingly saline water in the middle, and it is common among the many known caves along the littorals of the Croatian karst (Radić Rossi \& Cukrov, 2017 and references therein). 


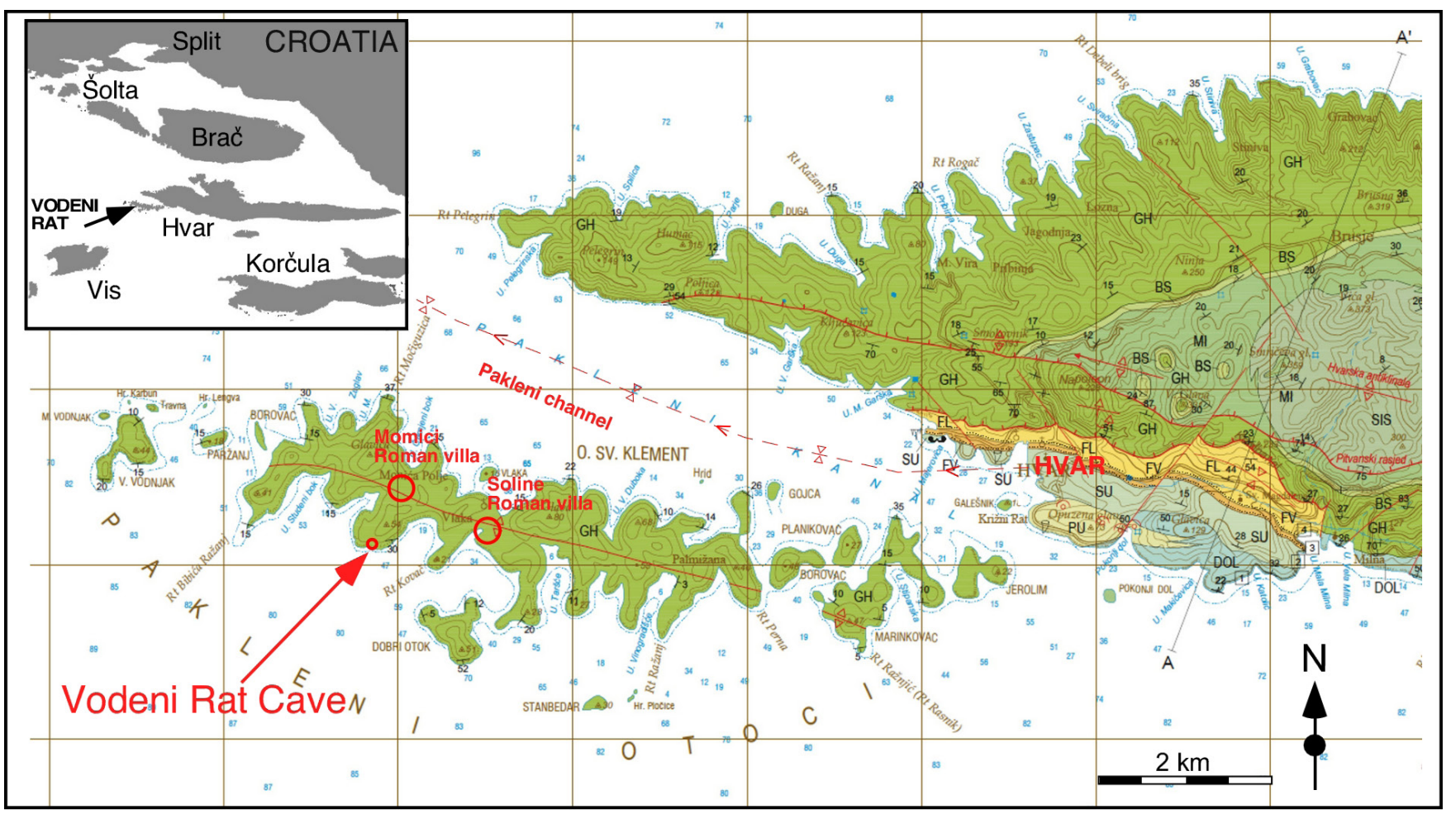

Fig. 1. Location map of Vodeni Rat Cave. Geologic base map from Oštrić et al. (2015).

The cave of Vodeni Rat was first explored in the summer of 1999 by a team of cavers and speleo-scuba divers from the speleoclub Špiljar of the city of Split, during a surveying campaign of karstic caves in the Dalmatian islands in search of potential potable water sources (Mesić, 2006). During that expedition, the speleologists found out that the cave was essentially a narrow, $\sim 13 \mathrm{~m}$ deep vertical shaft ending on a water pool, which measured $\sim 1.5-2 \mathrm{~m}$ in width, $\sim 6-8$ $\mathrm{m}$ in length, and $\sim 29 \mathrm{~m}$ in depth. The water column was clearly stratified with saline, somewhat turbid water at depth, and fresh clear water at the surface. Despite the scarce visibility, especially at depth in the saline part of the water column, the scuba divers noted the presence of broken ceramic vases and four well-preserved amphoras laying on the side over a rocky ledge at about $24 \mathrm{~m}$ water depth (i.e., $24 \mathrm{~m}$ below mean sea level). This archeological discovery was immediately reported to the local authority at the Heritage Museum of Hvar, and on December 8 of the same year an expedition was organized and lead by archeologist Jasen Mesić, with the main goal of retrieving, classifying, and preserving the archeological finds. In addition to Mesić, nine other people participated in the expedition, including speleologists and scuba divers from the speleoclub Špiljar, archeologist Marinko Petrić from the Heritage Museum of Hvar, and a logistical support team of local people (Petrić, 2017). The difficult operation of recovery of the archeological finds was first described in a report written in Italian by Mesić (2006), in a book chapter in Croatian by Petrić (2017), and ultimately in an abridged account in English by Radic Rossi \& Cukrov (2017). The whole operation of recovery, including the dive to the bottom of the cave pool at $\sim 29$ m below mean sea level, was filmed and the original videotape is presently preserved at the Heritage Museum of the City of Hvar, along with the retrieved amphoras now exposed in the adjoined archeological museum.

\section{Cave archeometry}

The archeological finds in the cave of Vodeni Rat undoubtedly indicated that in antiquity this freshwater source was exploited for a long period of time. A massive, 95- $\mathrm{cm}$-tall and essentially intact Lamboglia-2 type amphora found on the submerged ledge at $24 \mathrm{~m}$ water depth (i.e., $24 \mathrm{~m}$ below mean sea level and about $37 \mathrm{~m}$ below the entrance of the cave) dates back from the $2^{\text {nd }}$ century $\mathrm{BCE}$ to the first half of the $1^{\text {st }}$ century $\mathrm{CE}$, whereas a perfectly preserved 52-cm-tall LR-1 type amphora found next to it (Mesić, 2006; Petrić, 2017) was likely manufactured somewhere in the northeastern Mediterranean region (i.e., Cilicia province of southeastern Turkey, or Cyprus) from the second half of the $4^{\text {th }}$ to the early $7^{\text {th }}$ century CE (e.g., Piéri, 2005; Reynolds, 2005). Both these amphoras were internally coated with stillpreserved pitch (Mesić, 2006), indicating that they were meant to contain liquids. According to Mesic (2006), these amphoras were purposely left on the ledge, which was located on the side off the vertical line of the well, and served to scoop up freshwater at the bottom of the 37-m-deep vertical shaft. The precious potable water was probably lifted up and out the well in goat skin water bags (uter in Latin), which would not break when banging on the walls of the narrow shaft, and would have been easily transported on donkey back to the Roman villa rustica (i.e., a farm) of Momici, some $700 \mathrm{~m}$ to the northeast of the cave, or the larger villa maritima of Soline, about 1,500 m to the east of the cave (see Fig. 1 for location), both dating to the first half of the $1^{\text {st }}$ century CE (Begovic et al., 2013). Probably, the drinking water of Vodeni Rat was also utilized by passing-by sailors who could easily and safely dock in the Uvala Okorisa, a deep 
cove constantly protected from winds and waves, and located just $400 \mathrm{~m}$ to the north of the cave.

During the expedition of 1999, the speleo-scuba divers also reported crafted wooden beams wedged into the rock walls of the cave presently at 6 and $9 \mathrm{~m}$ water depth, which probably represent the remnants of some permanent infrastructure such as a scaffolding that would have facilitated the non-trivial operation of lifting up the water (Mesić, 2006). Speleo-scuba divers also reported abundant raw wood remains at the very bottom of the cave's water pool, which probably represented torches or possibly pieces of stepladders as parts of the scaffolding. This operation of water lifting certainly needed several people at work, down inside the cave standing on the ledge 37 $\mathrm{m}$ below the cave entrance to fill up the water bags (or any other type of unbreakable container such as a wooden bucket), and outside the cave to lift up with ropes the containers filled up with precious drinking water (Fig. 2A).

In fact, the southeastern rim of the cave entrance is incised by four $\sim 1$-cm-wide grooves, the longest
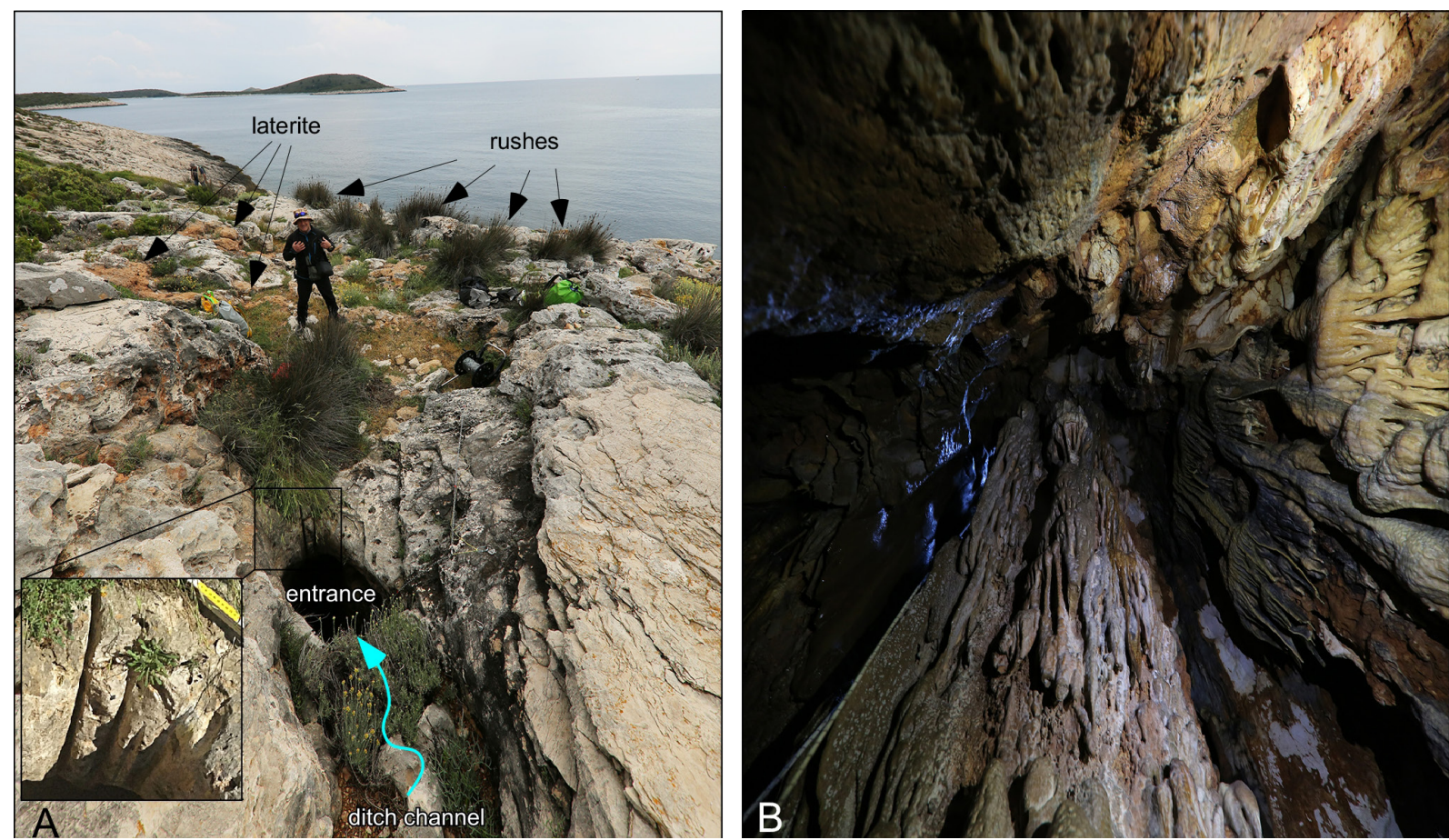

Fig. 2. A) Panoramic view of the Vodeni Rat site. In the distance, the Islet of Dugi Otok. (photo by A. Montanari); B) The speleothem-covered walls of the Vodeni Rat Cave looking up from the "bridge" (see Fig. 6 for location) (photo by S. Recanatini).

of which is about $10 \mathrm{~cm}$ deep (see inset in Fig. 2A), which were produced by the abrasive friction of ropes. All this indicates that the operation of uplifting water bags or other containers with ropes by one or more people standing outside the cave entrance has been going on for a long period of time, from the $2^{\text {nd }}$ century $\mathrm{BCE}$ to the $4^{\text {th }}-7^{\text {th }}$ century $\mathrm{CE}$, as suggested by the typology of the amphoras.

All these archeological and speleologic evidences strongly suggest that until the $4^{\text {th }}-7^{\text {th }}$ century CE the cave at Vodeni Rat was not an anchialine cave, i.e., a "tidally-influenced subterranean estuary..." (Bishop et al., 2015), but rather a $37 \mathrm{~m}$ deep karstic crevice with at the bottom a pool of fresh, potable water of probable meteoric origin. Eventually, sometime after the $4^{\text {th }}-7^{\text {th }}$ century CE, during the so-called Dark Ages Cold Period (DACP, Helama et al., 2017 and references therein), the Roman villas were abandoned, highly saline water started to infiltrate into the cave through joints and fissures of the surrounding limestone bedrock, and ultimately it mixed up with the cave's freshwater. Water became brackish and its level rose some $24 \mathrm{~m}$ up to sea level, flooding up what used to be the dry part of the cave. Nevertheless, a superficial layer of light freshwater persisted floating over the denser saline water. This freshwater layer would have been replenished and maintained by the runoff of meteoric water channeled in a small natural ditch on the up-slope side of the cave entrance (Fig. 2A). In summary and by analogy, the cave hydrology would be like the one of an impluvium (i.e., an underground cistern) connected via a narrow well to an external compluvium, i.e., a structure meant to collect and concentrate rainwater through gutters and drainage grates. Of course the cistern has to be waterproof so to prevent seepage. In the case of the Vodeni Rat Cave, the waterproofing was provided by thick speleothemic calcite of voluptuous flowstones and stalactites, which completely coat the inner walls of the cave down to about 23 m below mean sea level (Mesić, 2006; see Fig. 2B). By analogy, this speleothemic coating would be like the pitch, which coats the inner walls of otherwise porous ceramic containers meant to hold liquids. Mesić, (2006) hypothesized that sometime in the Early Medieval Period, "tectonic perturbations" (probably alluding to earthquakes) caused the rupture of this waterproofing speleothemic sealing following fracturing of the encasing limestone bedrock.

\section{Serendipitous discovery of stygobitic crustaceans in the cave of Vodeni Rat}

The availability of potable water just 30-m-distance from the sea in a small, dry rocky island like Sveti Klement certainly represents an interesting aspect of 
the link between human history and geologic history of this particular place, as it was recounted by Mesić (2006). On October 7, 2015, after visiting the ruins of the Roman villa at Soline, and studying the pedology of the adjoined 6 ha ager $\left(60,000 \mathrm{~m}^{2}\right)$, i.e., the Roman farmland, we went to Vodeni Rat to check the cave and the surrounding environment. We wanted to try the "bottle test", which entailed lowering a 1.5 liter clear plastic bottle with a ballast weight attached at the end of a line down the 13-m-deep shaft until getting it completely full of water, finding it agreeably sweet and drinkable. However, we noticed a white animal, about $1 \mathrm{~cm}$ long, swimming in the water bottle. The animal, which at first glance appeared to be an amphipod from the way it swam "belly-up", was extracted from the bottle and fixed in 95\% ethanol, and later on it was first sent to one of us at the GeorgAugust-Universität in Göttingen, Germany for a first identification, and then to one of us at the Université libre de Bruxelles for DNA sequencing.

On June 7, 2017, we returned to the cave of Vodeni Rat, this time armed with a closing Nansen net with a 50-ml Falcon tube as catcher, with which we caught a number of meiofauna organisms by blindly lowering it down to the freshwater pool with a line. A first study of the collected specimens was carried out at the universities of L'Aquila and Brussels (Fig. 3).

In the expedition of May 2018, we collected more samples with the Nansen net and also with a Cvetkov net specifically to collect faunal samples at various

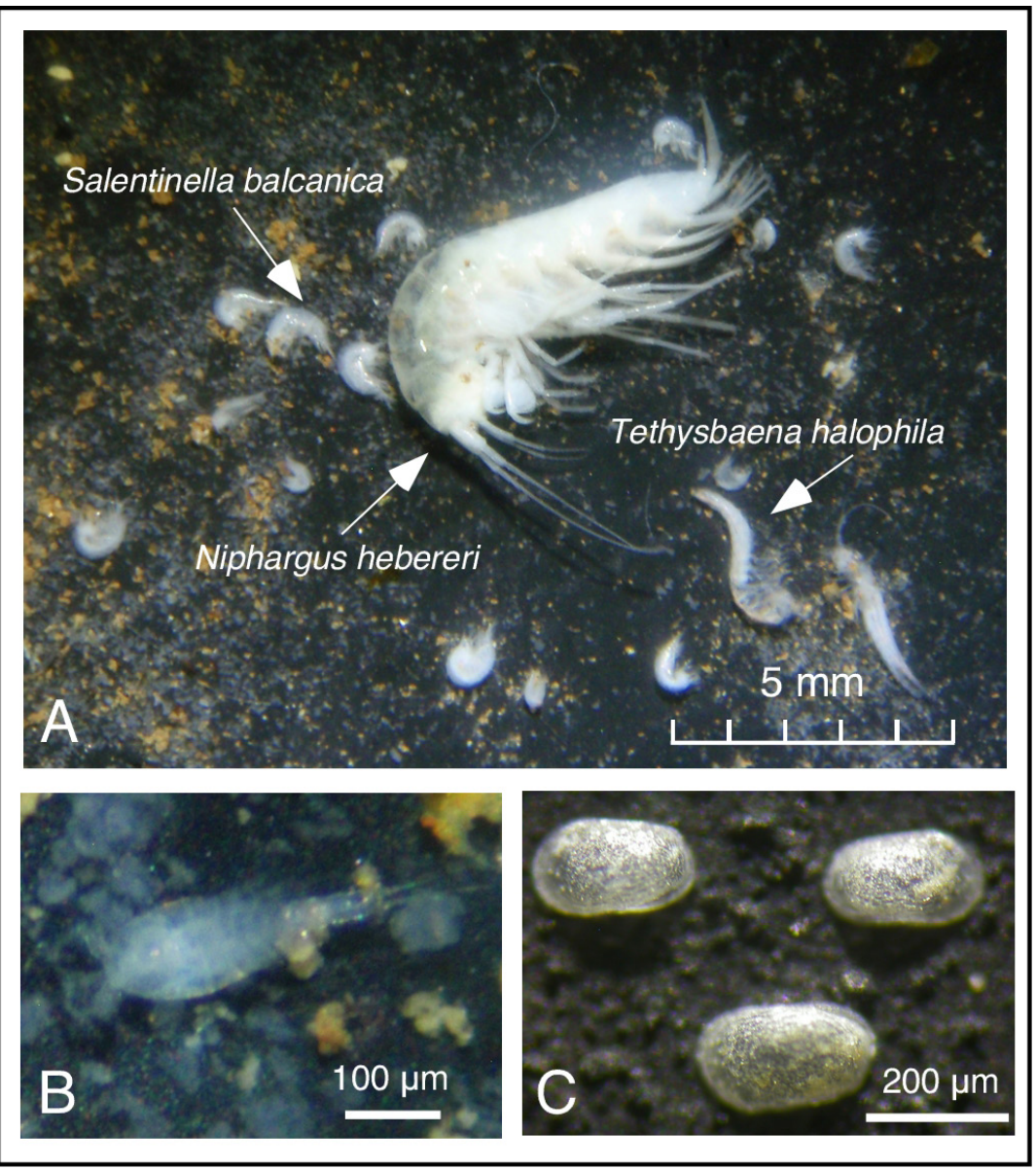

Fig. 3. First reconnaissance of crustaceans in the catch of the day at Vodeni Rat on June 2017 (Zeiss dissecting stereomicroscope photographs by A. Montanari). A) Amphipods and thermosbaenaceans; B) The copepod Halicyclops dalmatinus (male); C) Valves of the ostracod Pseudolimnocythere sp. depths in the water column. In addition, we carried out a thorough, detailed survey of the environment surrounding the cave. The upper dry part of the cave was also inspected and sketched, whereas the water column was analyzed for temperature, $\mathrm{pH}$, electric conductivity, and salinity with an immersion probe down to $21.5 \mathrm{~m}$ water depth.

In this paper, we describe in detail the geological, geomorphological, and biological characteristics of the environment surrounding the cave of Vodeni Rat, the physical properties of the water column of the saturated part of the cave, the systematics and ecology of the collected stygobitic crustaceans, and will discuss about the timing of the crustacean colonization of this cave on the basis of geologic, geochronologic, and archeometric evidences.

\section{GEOLOGIC AND ENVIRONMENTAL SETTINGS}

The small Pakleni archipelago represents one of a series of WNW-ESE trending anticlinoria making up the great islands of the central Dalmatian archipelago such as Korčula (the most external), Hvar, Brač, and Šlta (see inset of Fig. 1). In turn, these structures belong to the late Paleogene external Dinaride orogenic complex (e.g., Korbar, 2009; Surić et al., 2014 and references therein). These islands are all made up of limestones of the lower Cretaceous to lower Paleogene succession of the Adriatic Carbonate Platform (ACP in

Korbar et al., 2010, 2015; Oštrić et al., 2015 and references therein). The Campanian Gornji Humac Formation (84-72 Ma) is the one exposed at Vodeni Rat (Fig. 1), and represents a succession of mediumto-thick bedded hard limestones including pelletal foraminiferal wackestones, rudist flowstones, and cryptoalgal laminites (Oštrić et al., 2015), with a southern dip of $\sim 30^{\circ}$. The location of the cave entrance can be spotted from the off-shore distance on the steep, barren supralittoral zone of the island just below the edge of the tree line at the western end of an unusually extensive Juncus acutus grove, a salttolerant rush plant, which is normally very rare in dry, rocky environments such as the karstic littorals of the Dalmatian islands (e.g., Pandža \& Milović, 2015; see Fig. 4A). A grove of less conspicuous Junkus maritimus rushes is spread on the rocky area to the west of the cave entrance but it is too seemingly out of place inasmuch this rush species is endemic of sandy, salty, and humid habitats (Fig. 4B).

The limestone beds exposed at Vodeni Rat are pervasively crisscrossed by systems of pressure-solution cleavage and joints with various orientations (Fig. 4B). Two sub-vertical $\sim$ NNE-SSW-striking minor faults of undetermined offset delimit the area where most of the Juncus rush plants are concentrated. A part from the 

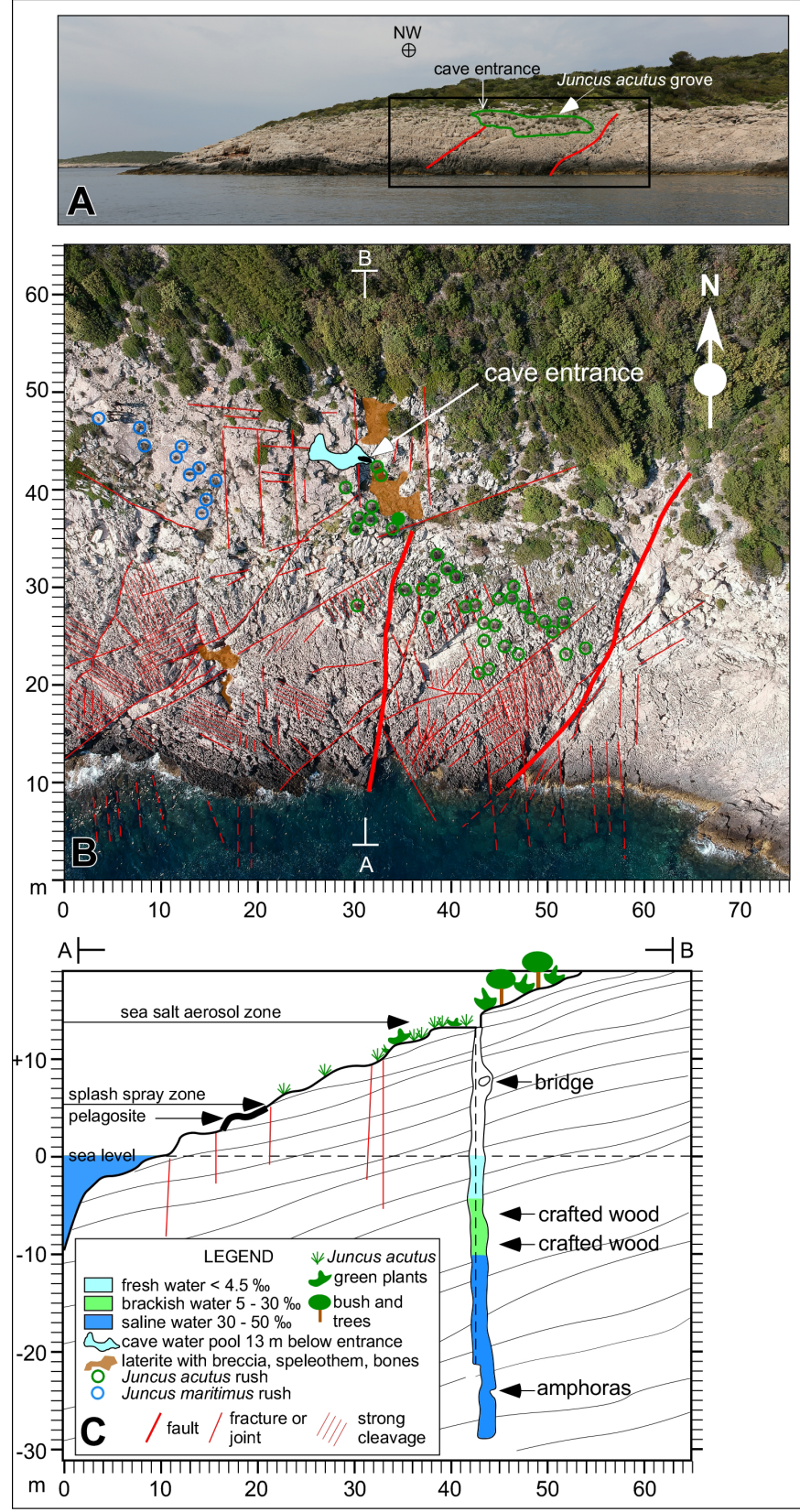

Fig. 4. A) Panoramic view of Vodeni Rat as seen from offshore (photo by A. Montanari); B) Structural setting of the Vodeni Rat site as mapped on a drone orthophotograph (photo by M. Mainiero); C) Cross section and physiography of the Vodeni Rat littoral zone.

Juncus groves, the environmental physiography of the supralittoral zone at Vodeni Rat (Fig. 4C) reflects well the model of Montanari et al. (2019), which was originally defined at Point Pleturina on the southern littoral of the Island of Hvar, some $3 \mathrm{~km}$ east from the homonym city. In the immediate surrounding of the cave entrance, the limestone does not exhibit any particularly severe fracturing or jointing, nor there seems to be a $\sim \mathrm{E}$-W-striking vertical fault onto which the $\sim 42$-m-deep karstic crevasse with a roughly $\mathrm{E}-\mathrm{W}$ elongation has developed. On the other hand, around the cave entrance there are conspicuous deposits of laterite (Fig. 2B). Horizons and intrusions of laterite and bauxite are commonly found in the mid Eocene limestone succession of the ACP, which indicate a paleokarst underlying a subaereal surface that represents a well-known regional unconformity (Brlek et al., 2014). By contrast, the laterite deposit around the cave of Vodeni Rat is a paleokarst feature attributable to the Pleistocene karstification of the Dalmatian limestones once they were deformed, uplifted, and exposed following the early Neogene orogenic phase of the external Dinarides (Korbar, 2009). These irregular rust-orange rock bodies are found everywhere around the Pakleni islands as well as in different limestone formations throughout the Hvar main island, and they all seem to fill up cavities or cracks within the karstified limestone. They often comprise limestone breccia and animal bones, but also speleothemic concretions and inclusions of blocky calcite (Fig. 5).

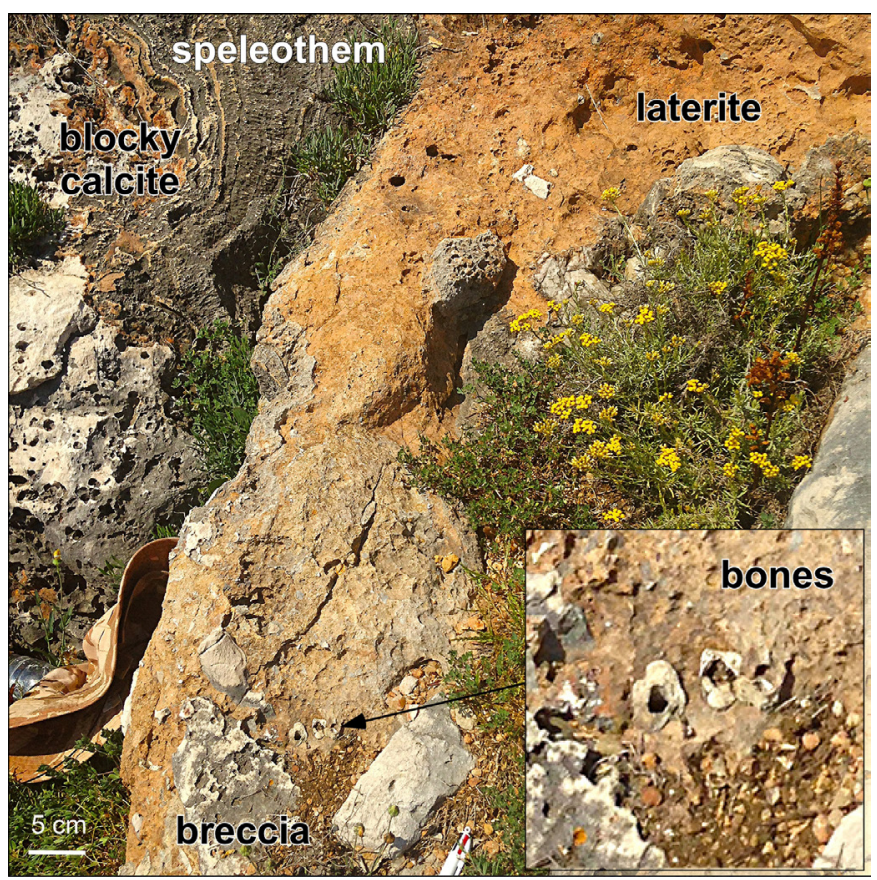

Fig. 5. Close up image of the laterite deposit around the cave of Vodeni Rat (photo by A. Montanari).

A sample of blocky calcite from the Vodeni Rat laterite was dated at the Massachusetts Institute of Technology (USA) with the U-Th method (see Montanari et al., 2020, for dating method and technique), and yielded an age of $302.5 \pm 6.3 \mathrm{ka}$ (Table 1) indicating that karstic processes and speleothemic concretion were occurring here in the late Middle Pleistocene. This date suggests that the surface topography of the Pakleni islands did not change much since the Middle Pleistocene. However, the Pakleni channel that separates the archipelago from the island of Hvar (Fig. 1), is likely a synformal structure between the Hvar and the Pakleni anticlinoria, with a NW plunging axis that deepens from the harbor of Hvar to about $70 \mathrm{~m}$ below mean sea level at the northwestern end of the channel. This structural setting suggests that the Pakleni channel may represent a now submerged synclinal fluvial valley, which was incised following the orogenic emersion of the external Dinaride.

During the Last Glacial Maximum (LGM) some 25 thousand years ago, the physiography of the Dalmatian islands was very different from the present. For one thing, sea level was about $130 \mathrm{~m}$ lower than it is today and the Adriatic coast line was some $30 \mathrm{~km}$ to the south of Vodeni Rat. Practically, the islands of Brač, Hvar, and Korčula were rocky hills separated by the now submerged valleys of the Cetina and Neretva 
Table 1. Results from U-TH analysis of speleothemic blocky calcite from Vodeni Rat (Islet of Sveti Klement, Hvar, Croatia)

\begin{tabular}{|c|c|c|c|c|c|c|c|c|c|c|c|c|c|c|c|c|c|}
\hline $\begin{array}{c}\text { MIT } \\
\text { McGee } \\
\text { Lab }\end{array}$ & Sample & ${ }^{238} \mathrm{U}$ & $\begin{array}{c} \pm \\
(2 \sigma)\end{array}$ & ${ }^{232} \mathrm{Th}$ & $\begin{array}{c} \pm \\
(\mathbf{2 \sigma})\end{array}$ & $\delta^{234} U$ & $\begin{array}{c} \pm \\
(2 \sigma)\end{array}$ & $\begin{array}{l}{ }^{230} \mathrm{Th} / \\
\left.{ }^{238} \mathrm{U}\right)\end{array}$ & $\pm(2 \sigma)$ & $\begin{array}{l}{ }^{230} \mathrm{Th} / \\
{ }^{232} \mathrm{Th}\end{array}$ & $\begin{array}{c} \pm \\
(2 \sigma)\end{array}$ & Age (yr) & $\begin{array}{c} \pm \\
(2 \sigma)\end{array}$ & $\begin{array}{c}\delta^{234} \mathrm{U} \\
\text { initial }\end{array}$ & $\begin{array}{c} \pm \\
(2 \sigma)\end{array}$ & $\begin{array}{c}\text { Age } \\
(\mathrm{yr} \mathbf{B P})^{\mathrm{f}}\end{array}$ & $\pm(2 \sigma)$ \\
\hline sample ID & description & $\begin{array}{c}(\mathrm{ng} / \\
\mathrm{g})^{\mathrm{a}}\end{array}$ & & $\begin{array}{c}(\mathrm{pg} / \\
\mathrm{g})^{\mathrm{a}}\end{array}$ & & $\begin{array}{l}(\text { per } \\
\text { mil) }\end{array}$ & & activity & & $\begin{array}{c}\mathrm{ppm} \\
\text { atomic }\end{array}$ & & (uncorrected) $^{\mathrm{c}}$ & & $\begin{array}{l}(\text { per } \\
\text { mil) }\end{array}$ & & $(\text { corrected) })^{\mathrm{e}}$ & \\
\hline VDR-CAL & $\begin{array}{l}\text { blocky } \\
\text { calcite }\end{array}$ & 47 & 1 & 4488 & 90 & 28 & 2 & 0.9740 & 0.0027 & 160 & 0.3 & 305300 & 6100 & 66 & 5 & 302400 & 6300 \\
\hline
\end{tabular}

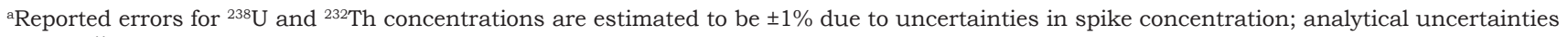
are smaller;

${ }^{\mathrm{b}} \mathrm{C}^{234} \mathrm{U}=\left(\left[{ }^{234} \mathrm{U} /{ }^{238} \mathrm{U}\right]\right.$ activity - 1) x 1000

$\left.{ }^{c}{ }^{230} \mathrm{Th} /{ }^{238} \mathrm{U}\right]$ activity $=1-\mathrm{e}^{-1230 \mathrm{~T}}+\left(\delta^{234} \mathrm{U}^{\text {measured }} / 1000\right)\left[\lambda^{230} /\left(\lambda^{230}-\lambda^{234}\right)\right]\left(1-\mathrm{e}^{-(1230-1234) \mathrm{T}}\right)$, where $\mathrm{T}$ is the age. "Uncorrected" indicates

that no correction has been made for initial ${ }^{230} \mathrm{Th}$;

${ }^{d} \delta^{234}$ Uinitial corrected was calculated based on ${ }^{230} \mathrm{Th}$ age $(\mathrm{T})$, i.e., $\delta^{234} \mathrm{U}^{\text {initial }}=\delta^{234} \mathrm{U}^{\text {measured }} \mathrm{X}$ el234*T , and T is corrected age;

eAges are corrected for detrital ${ }^{230} \mathrm{Th}$ assuming an initial ${ }^{230} \mathrm{Th} /{ }^{232} \mathrm{Th}$ of $(4.4 \pm 2.2) \times 10^{-6}$;

fBP stands for "Before Present" where the "Present" is defined as the January 1, 1950 C.E.;

Decay constants for ${ }^{230} \mathrm{Th}$ and ${ }^{234} \mathrm{U}$ are from Cheng et al. (2013); decay constant for ${ }^{238} \mathrm{U}$ is $1.55125 \times 10^{-10} \mathrm{yr}^{-1}$ (Jaffey et al., 1971 ).

rives (Pavelić et al., 2011; Pavelić et al., 2014; Wacha et al., 2019). Aeolian sands deflated from the then dry Adriatic seafloor were blown over the exposed sides of the most external (western) of these mountainous reliefs, such as the present island of Vis (see Fig. 1 for location) by the southerly Jugo wind, building up conspicuous sand deposits (Wacha et al., 2019). The Soline ager is, in fact, a rare case of arable land in the arid karstic environment of the Dalmatian islands exactly because its fertile and water-retaining soil is derived from one of these LGM aeolian sand deposits.

Vertical GPS velocities in selected locations in northwestern Croatia indicate that the internal Dinaride is presently uplifting whereas the external Dinaride is subsiding (Surić et al., 2014). A part from some localized cases where emerged tidal notches suggest a slight uplift (e.g., the Dubrovnik coast; Surić et al., 2014), which surpassed the generalized tectonic subsidence of the external Dinaride domain, geomorphic features such as sublittoral caves and other karstic features found below sea level, submerged tidal notches, and supratidal pelagosite encrustation (Surić \& Juračić, 2010; Montanari et al., 2019) they all indicate that coastal caves such as the one at Vodeni Rat represent an ancient relict karst, which developed in a continental environment at much higher elevations during the Pleistocene, and ultimately reached sea level or drowned below it following of a slow, generalized post-orogenic subsidence.

\section{SAMPLING}

Biological samplings were done by lowering, with a $6 \mathrm{~mm}$ nylon line, a Nansen closing net with a $30-\mathrm{cm}-$ diameter iron rim and a $50 \mathrm{ml}$ Falcon tube as a catcher, from the rim of the cave entrance down until touching the surface of the water pool (Fig. 6).

The net was then dipped a meter or so into the water and slowly lifted up and out in the air to let the water filling up the net to filter out through the $44 \mathrm{~mm}$ polyester mesh. Vertical hauls were repeated 20 times in free water (sample FREE in Fig. 6). The same technique was used to collect samples along the submerged side of the cave by having the rim of the net brushing against the rocky wall of the pool (sample WALL in Fig. 6). The catch was immediately fixed on site with 95\% ethanol, and the Falcon tube properly labeled, sealed with electrical tape, and made it ready to be sent to the biolab at the University of L'Aquila. In the last expedition to Vodeni Rat we used a phreatobiological Cvetkov net (Cvetkov, 1968) of 60 $\mu \mathrm{m}$ mesh size to collect at mid depths in the water column and also all the way down to about $21.5 \mathrm{~m}$ depth in the well, which was the maximum depth we could reach with our blind probing from the entrance of the cave (samples DEEP and BOTTOM in Fig. 6).

The physical properties of the water column including temperature, $\mathrm{pH}$, electric conductivity, and salinity, were analyzed with an YSI 600XLM immersion probe in continuity from $21.5 \mathrm{~m}$ water depth (maximum depth reachable with the probe from the rim of the entrance), up to water surface (Table 2).

The probe was attached at the end of a $5 \mathrm{~mm}$ steel chain with $50 \mathrm{~cm}$ markings and a weight to maintain

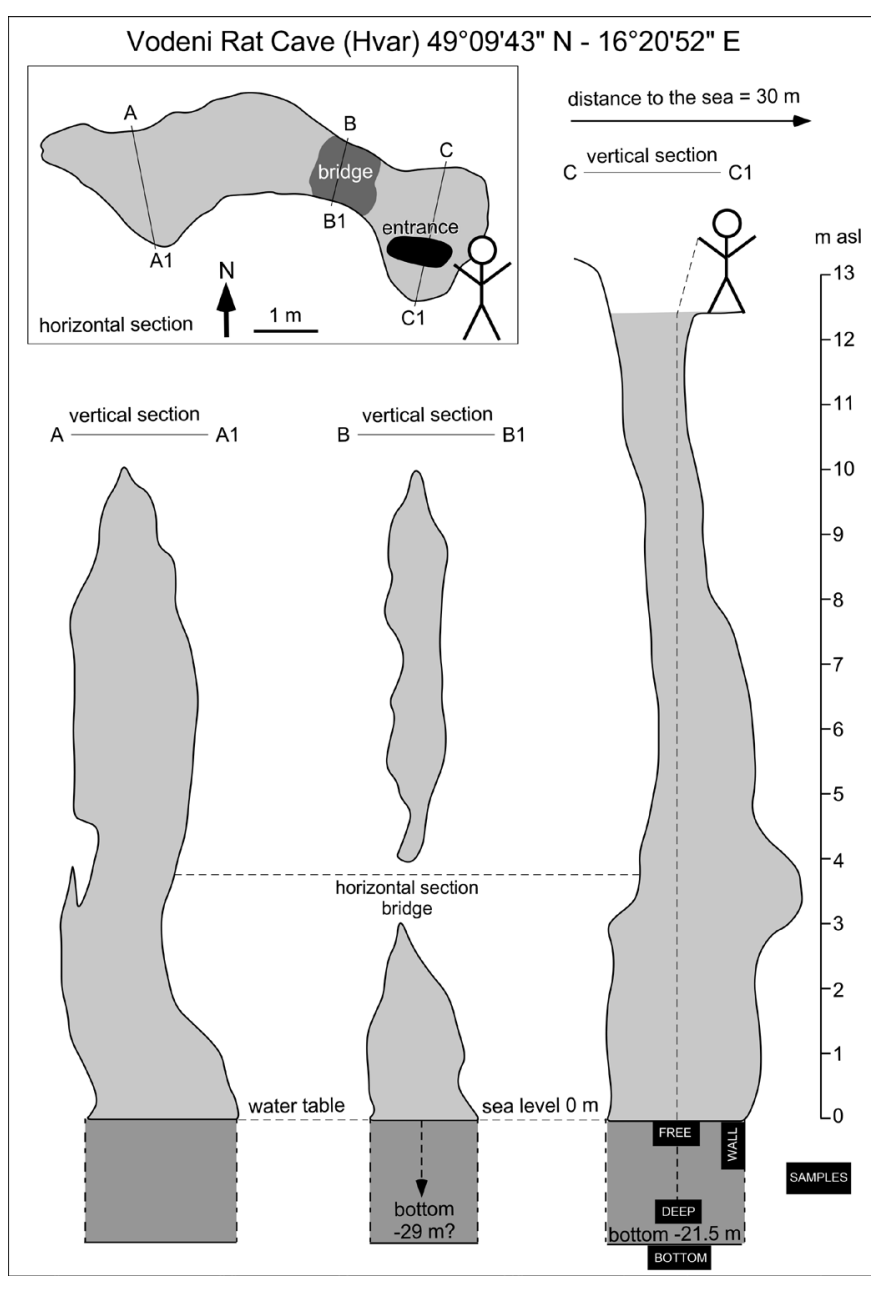

Fig. 6. Sketched horizontal and vertical sections of the cave of Vodeni Rat, and indication of the sampled underwater zones. 
Table 2. Immersion probe data from Vodeni Rat Cave (Croatia)

\begin{tabular}{|c|c|c|c|c|}
\hline $\begin{array}{l}\text { Water depth } \\
\text { (m) }\end{array}$ & $\begin{array}{c}\text { Temperature } \\
\left({ }^{\circ} \mathrm{C}\right)\end{array}$ & $\mathbf{p H}$ & $\begin{array}{l}\text { Conduct. } \\
(\mu \mathrm{S} / \mathrm{cm})\end{array}$ & Salinity (\%o) \\
\hline 0.985 & 17.59 & 7.80 & 3297 & 1.74 \\
\hline 1.801 & 17.68 & 7.80 & 3758 & 1.99 \\
\hline 2.889 & 17.73 & 7.83 & 4187 & 2.23 \\
\hline 3.699 & 17.74 & 7.83 & 4668 & 2.51 \\
\hline 4.413 & 17.74 & 7.77 & 6097 & 3.33 \\
\hline 5.195 & 17.72 & 7.61 & 8259 & 4.61 \\
\hline 6.089 & 17.70 & 7.43 & 15341 & 8.98 \\
\hline 6.765 & 17.69 & 7.36 & 21385 & 12.88 \\
\hline 7.545 & 17.66 & 7.27 & 26573 & 16.32 \\
\hline 8.219 & 17.63 & 7.19 & 31578 & 19.72 \\
\hline 8.975 & 17.61 & 7.14 & 41222 & 26.46 \\
\hline 9.556 & 17.60 & 7.14 & 44834 & 29.05 \\
\hline 10.122 & 17.57 & 7.11 & 48254 & 31.53 \\
\hline 10.801 & 17.53 & 7.07 & 53463 & 35.36 \\
\hline 11.556 & 17.48 & 7.05 & 57360 & 38.26 \\
\hline 12.542 & 17.44 & 7.03 & 57856 & 38.64 \\
\hline 13.895 & 17.40 & 7.03 & 57984 & 38.73 \\
\hline 14.606 & 17.38 & 7.02 & 58057 & 38.79 \\
\hline 15.562 & 17.35 & 7.02 & 58130 & 38.84 \\
\hline 16.364 & 17.33 & 7.01 & 58157 & 38.86 \\
\hline 17.417 & 17.31 & 7.01 & 58180 & 38.88 \\
\hline 18.290 & 17.29 & 7.01 & 58195 & 38.89 \\
\hline 19.188 & 17.26 & 7.00 & 58220 & 38.91 \\
\hline 20.018 & 17.25 & 7.00 & 58242 & 38.92 \\
\hline 20.881 & 17.22 & 7.00 & 58278 & 38.95 \\
\hline 21.496 & 17.20 & 6.99 & 58310 & 38.97 \\
\hline
\end{tabular}

Measurements done on 09/05/2018 from 14:48 to $14: 50 \mathrm{hrs}$.

it in tension and vertical in the water column. While temperature from $17.60^{\circ} \mathrm{C}$ at the surface increases by $0.15^{\circ} \mathrm{C}$ through the top $4 \mathrm{~m}$ of the water column to then gradually descend through the rest of the water column down to $17.20^{\circ} \mathrm{C}$ at $21.5 \mathrm{~m}$ water depth, all the other parameters indicate a well stratified water column with the top $4 \mathrm{~m}$ made up of freshwater (salinity $=<5 \%$ o), followed by a $4.5-\mathrm{m}$-thick mixing zone of brackish water (salinity $=5-30 \%$ o), and a bottom layer of essentially sea water (salinity $=\sim 40 \%$ o) (Fig. 7).

\section{SYSTEMATICS AND ECOLOGY OF STYGOBITIC CRUSTACEANS IN THE CAVE OF VODENI RAT}

\section{Ostracods}

From the WALL catch of June 2017, we hand picked 25 well-preserved single valves of a tiny ostracod that we identified as Pseudolimnocythere sp. (Figs. 3C and 8).

Unfortunately, no soft parts nor paired and closed articulated valves were found in that batch, and so it was impossible to identify the actual species. Nevertheless, this genus is very interesting inasmuch it belongs to the family of Loxoconchidae Sars, 1925, which consists mostly of marine or brackish water species. The only other genera of this family, which occur in fresh or brackish waters, are Cytheromorpha Hirschmann, 1909 (some species in Europe) and Sanyuania in Thailand. There are only two known m bmsl Temperature ${ }^{\circ} \mathrm{C}$

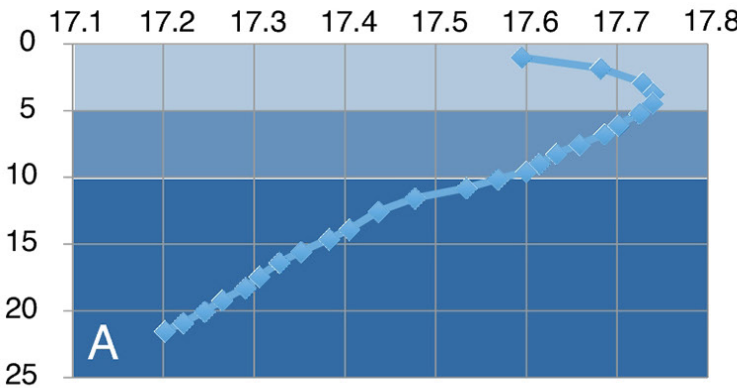

m bmsl $\quad \mathrm{pH}$
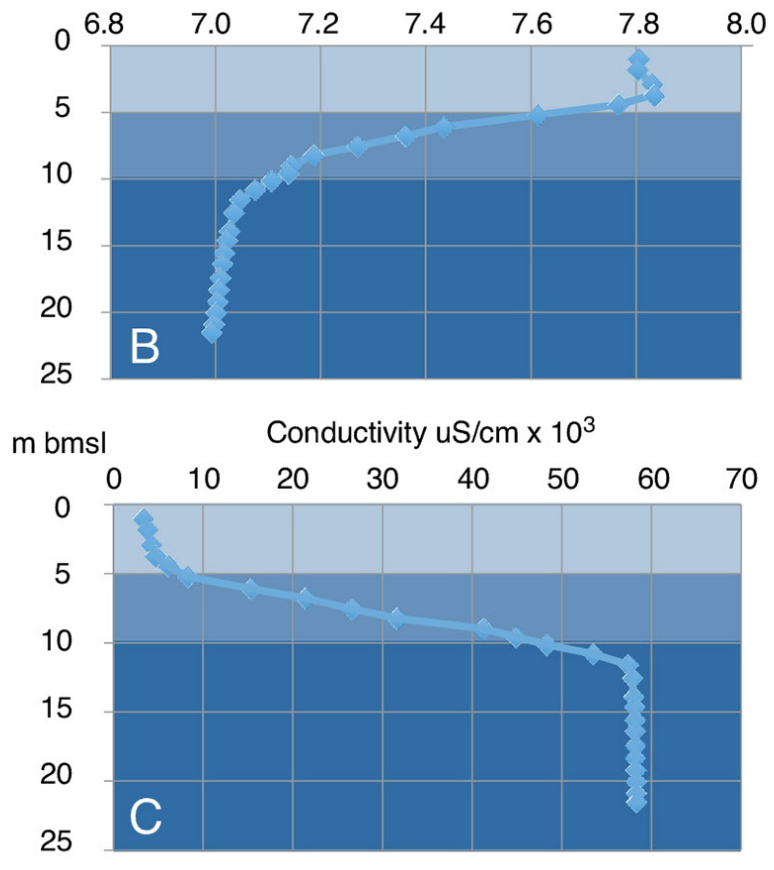

$\mathrm{m}$ bmsl Salinity \%。

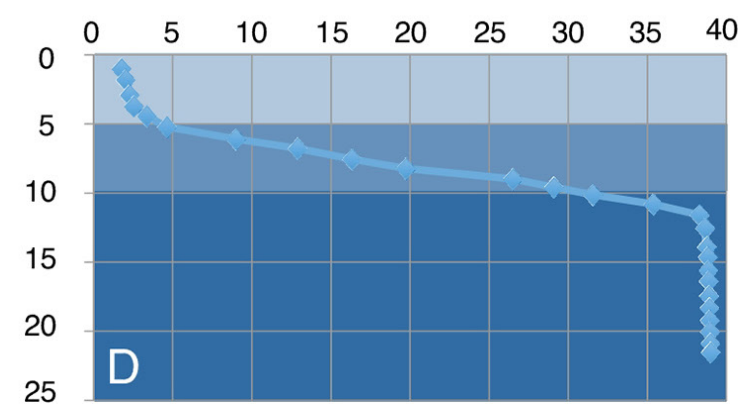

water salinity

$\begin{array}{ll}\text { fresh } & <5 \% \\ \text { brackish } & 5-30 \% \text { o } \\ \text { saline } & 30-50 \% \text { o }\end{array}$

Fig. 7. Profiles of A) temperature; $\mathrm{B}$ ) $\mathrm{pH}$; C) electrical conductivity; D) temperature, through the water column of the Vodeni Rat cave (see raw data in Table 2).

recent species belonging to Pseudolimnocythere Klie, 1938, one of which seems to be endemic to southern Italy - Pseudolimnocythere hypogaea described by German ostracodologist Klie (1938) from wells in Bari, and resampled by Karanović \& Pesce (2001) from underground freshwaters in Apulia (southeastern Italy). The second recent species of the genus is Pseudolimnocythere hartmanni described from wells and interstitial habitats of Euboea Island (Greece) 


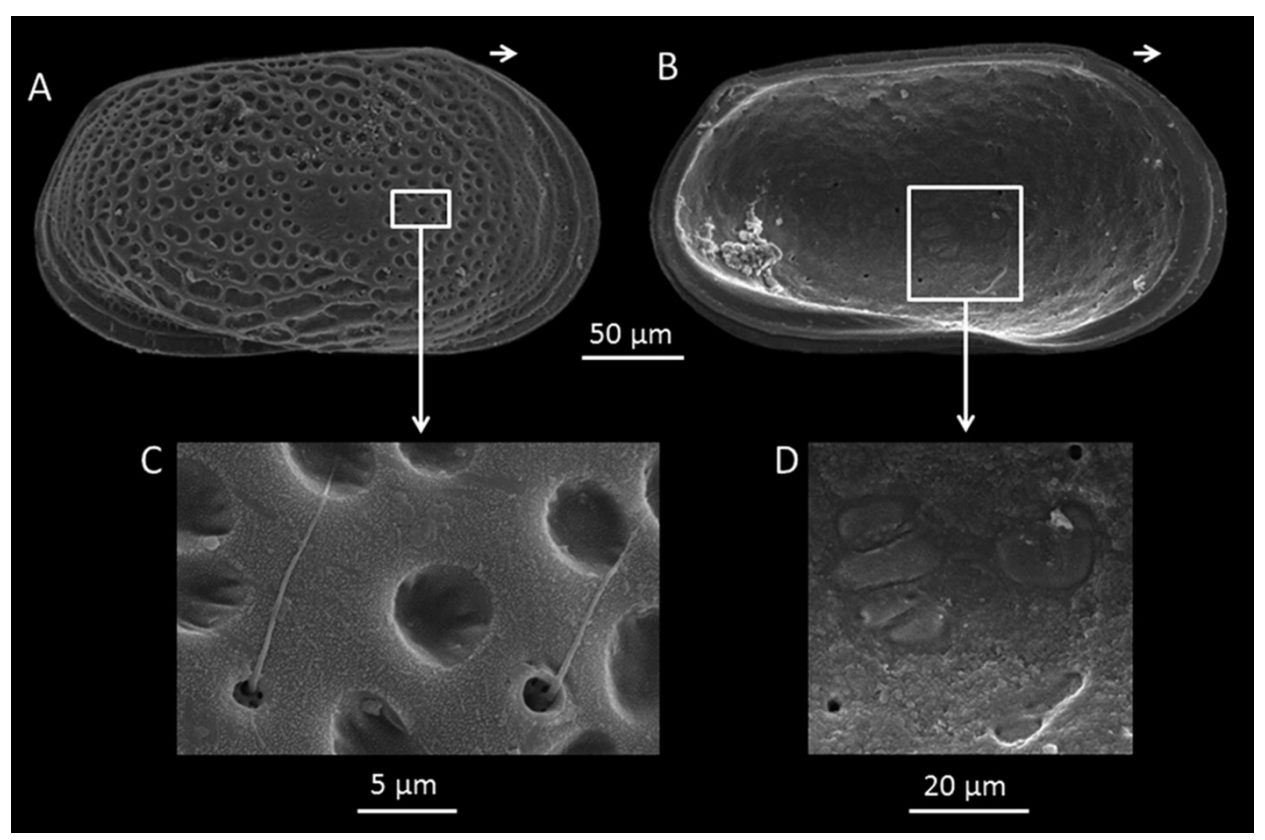

Fig. 8. SEM images of ostracod Pseudolimnocythere sp. from the cave of Vodeni Rat. A) Right valve external view (length $=278 \mu \mathrm{m})$; B) Left valve internal view (length $=281 \mu \mathrm{m})$; C) Detail of ornamentation and two sieve pores; D) Detail of muscle scars (photos by T. Namiokto).

by Danielopol (1979). There are some more recent/ subfossil records of Pseudolimnocythere from Italy, as a spring near Parma and karst springs in the Secchia River valley in the northeastern Apennines (Pieri et al., 2015 and references therein). Peterson et al. (2013) found over a thousand valves of Pseudolimnocythere sp. in phreatic waters of the Frasassi cave complex but only a few of them in the adjacent Sentino River. All these findings are left in open nomenclature as Pseudolimnocythere sp., being so small, is extremely difficult to identify taxonomically from just the valves. There is also one fossil species Pseudolimnocythere hainburgensis described by Danielopol et al. (1991) from Miocene fresh or brackish water deposits of the Vienna Basin. Very interestingly, Danielopol (1980) in a paper on the origin of European interstitial freshwater ostracods mentioned and illustrated one more species of Pseudolimnocythere (also left in open nomenclature Pseudolimnocythere sp.) from the Škuljica Cave, near a lighthouse in the southeastern tip of the Krk Island, some $400 \mathrm{~km}$ north from Vodeni Rat along the Croatian shore of the Adriatic Sea. Supposing that ancestors of Pseudolimnocythere were originally marine species, Danielopol (1980) proposed two hypotheses of how representatives of this genus became continental hypogean species. Hypothesis 1: the Pseudolimnocythere species penetrated into the inland subterranean waters during one of the many Pleistocene regressive-transgressive phases. Hypothesis 2: the Pseudolimnocythere species penetrated into the inland subterranean waters during the Upper Miocene - Lower Pliocene regressive phase (e.g., during the Messinian salinity crisis).

Danielopol's hypotheses are interesting and relevant for the Vodeni Rat neo-anchialine cave, and respond well to what Bonacci (2009) calls "Karst Ecohydrology", an extremely complex generalized model. But the issue becomes more complicated by the fact that submersion or emersion of karstic systems, which in any case can only form in subaereal regions, also depend on local tectonic movements, which can be uplift or subsidence regardless of eustatic sea level changes, and they may change or even reverse through geologic time. For instance, the Island of Krk where the Škuljica Cave contains Pseudolimnocythere sp. is presently uplifting at GPS velocities of about $4 \mathrm{~mm} / \mathrm{yr}$ (Surić et al., 2014). So during the LGM about $25 \mathrm{ky}$ ago, when sea level was $130 \mathrm{~m}$ lower than today, the Škuljica Cave was located about $30 \mathrm{~m}$ above sea level but during the last interglacial (the Eemian or MIS 5e), some $100 \mathrm{ky}$ ago, when sea level was about the same as today, the cave must have been located $400 \mathrm{~m}$ below sea level. But this gross calculation with the present GPS velocity does not work (probably because of their large analytical error) inasmuch submerged speleothems in the $U$ Vode anchialine cave in Krk Island at 13-18 m below mean sea level indicated that they were uplifted for approximately 13-18 m during the last $\sim 75-85 \mathrm{ka}$, so at an average velocity for that period of $\sim 0.15-0.25 \mathrm{~mm} / \mathrm{yr}$. Radic Rossi \& Cukrov (2017) summarized that "...The chronological determinations of these and 12 other speleothems from five different caves (taken up to a depth of $41.5 \mathrm{~m}$ ) were realized with three different dating techniques. The results allowed Suric et al. (2014) to reconstruct a partial sea-level curve for the Croatian part of the Eastern Adriatic coast for the last 220,000 years (Suric \& Juračić, 2010), and to suggest the dynamics associated with the palaeoenvironmental changes" since the late Middle Pleistocene.

On the other hand, the anchialine caves on the western coast of the Istrian peninsula, which is presently subsiding at GPS velocities of about $4 \mathrm{~mm}$ / yr, would have had a different history. Practically, they should have been well above sea level all the time during the Pleistocene, of course if subsidence was going on uninterrupted during the whole Epoch. This is because the Istrian Peninsula along with the central Dalmatian Archipelago (so including the island of Sveti Klement) belong to the external Dinaride tectono- 
stratigraphic unit, which is in a generalized regime of subsidence, as opposed to the internal Dinaride unit, which includes the Island of Krk and the northern Dalmatian archipelago (e.g., Kvarnar, Kornati) as well as the Dinaric fold and thrust mountain belt as a whole, which are presently in a generalized regime of tectonic uplift. Going back to the primordial marine origin of the Pseudolimnocythere sp., it could well be that both hypotheses 1) and 2) of Danielopol (1980) are right to some extent, in the sense that since the Miocene at least, this marine ostracod lineage (as it seems to be in the fossil record of the Vienna Basin) may have penetrated into the inland subterranean waters from the sea at different times in different places (such as Frasassi, Euboea, Krk, Apulia, Parma, Secchia valley, and Vodeni Rat), and in each case, it became a different species (or possibly there were different species in the beginning within different parts of the western Tethyan or Paratethyan seas). Only $P$. hartmanni and $P$. hypogea, both with soft parts, were formally described so far as different recent freshwater species.

\section{Copepods}

Biological samples were taken using a phreatobiological Cvetkov net, which allowed the collection of fauna at different water depths down to the bottom of the cave. Samples preserved in 95\% ethanol were sorted under a Leica M205C microscope and copepods were identified to the species level using a Leica DM2500 optical microscope. A total of 73 copepod specimens were collected. Two of them were assigned to the order Calanoida, being specimens at a very early stage of development and not well preserved thus preventing a finer taxonomic identification. Four copepod species were identified belonging to 3 different orders: Misophrioida (1 species), Cyclopoida (2 species) and Harpacticoida (1 species) (Table 3).

Table 3. Crustacea Copepoda from the cave of Vodeni Rat (Croatia).

\begin{tabular}{|c|c|c|c|c|}
\hline \multirow[b]{2}{*}{ Taxon } & \multicolumn{4}{|c|}{$\begin{array}{l}\text { Number of specimens per catch sample } \\
\text { name and relative water depth in } \mathrm{m} \text { below } \\
\text { mean sea level and salinity (parts per mil) }\end{array}$} \\
\hline & 묘 & 皇 & 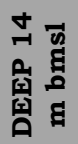 & 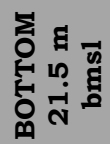 \\
\hline Speleophria mestrovi & 0 & 0 & 28 & 2 \\
\hline Calanoida indeterminate & 0 & 0 & 2 & 0 \\
\hline Halicyclops dalmatinus & 2 & 35 & 0 & 0 \\
\hline Diacyclops slovenicus & 0 & 2 & 0 & 0 \\
\hline \multirow[t]{2}{*}{ Parapseudoleptomesochra sp. } & 0 & 2 & 0 & 0 \\
\hline & \multicolumn{2}{|c|}{$1.7 \%$ о } & \multicolumn{2}{|c|}{$38.7-39.0 \%$} \\
\hline
\end{tabular}

All the species are strictly stygobites and commonly found in anchialine caves. In the cave of Vodeni Rat, they showed high habitat partitioning, with the misophrioid Speleophria mestrovi Kršinic, 2008 exclusively found in samples from the deepest part of the cave and near its bottom where the highest salinity values were measured. In the most superficial layers near the cave walls, 3 different species coexisted in a freshwater habitat (salinity $<2 \%$; Table 2). The dominant species was the cyclopoid Halicyclops dalmatinus Petkovski, 1955 (Fig. 3B). It belongs to the cosmopolitan genus Halicyclops Norman, 1903 of the family Halicyclopidae Kiefer, 1927 (Khodami et al., 2019). The genus includes planktonic and benthic species widely distributed in several kinds of coastal brackish water bodies among which many anchialine caves and sinkholes, but also in freshwater habitats. Before the present record, $H$. dalmatinus was documented in only a few brackish water bodies of Montenegro and in a single brackish water well near Bari (southeastern Italy) (Petkovski, 1955; Pesce et al., 1984). The cyclopoid Diacyclops slovenicus Petkovski, 1954 was originally described from the Vrhnika karstic spring of Ljubljanica (Slovenia) and subsequently found in several other localities in Slovenia, Croatia, and Bosnia and Herzegovina (Brancelj, 1987; 1990; 2001; Culver \& Sket, 2000; Petkovski, 1954; 1984). The species is typical of the saturated karst and was found in the freshwater layer of the cave.
From a taxonomic perspective, Speleophria Boxshall \& Iliffe, 1986 is a very poorly diversified genus currently comprising six species, namely, S. bivexilla Boxshall \& Iliffe, 1986 (Bermuda); S. bunderae Jaume, Boxshall \& Humphreys, 2001 (Cape Range Peninsula, Australia); S. germanyanezi Suárez-Morales, Cervantes-Martínez, Gutiérrez-Aguirre \& Iliffe, 2017 (Yucatán Peninsula, Mexico); S. gymnesica Jaume \& Boxshall, 1996 (Mallorca Island, Spain); S. mestrovi (Vis Island; Croatia); S. nullarborensis Karanovic \& Eberhard, 2009 (Nullarbor Region, South-Western Australia).

All the species but $S$. mestrovi show a point geographic distribution, being at present known from a single cave and can be considered narrow endemics. On the contrary, S. mestrovi, originally described from Supurina Cave in Vis Island, some $30 \mathrm{~km} \mathrm{SW}$ of the Pakleni archipelago (Kršinic, 2008), is now recorded in the cave of Vodeni Rat in Sveti Klement Island during the present investigation.

Members of the genus Speleophria have a disjunct distribution. The species are spread out from the Caribbean area to the Mediterranean area and Australia, thus supporting a very ancient origin of the genus. The present distribution of Speleophria offers a good example of the so-called full 'Tethyan track' (Croizat, 1958). It covers the area flooded by the Tethys Ocean and by the seas originated by the Tethys fragmentation in the late Mesozoic 
(Galassi et al., 1999; Galassi, 2001, Humphreys, 2004). The ancestor of the genus Speleophria, distributed in a suitable habitat along the coastlines of the Tethys realm, probably underwent allopatric speciation by vicariance, in which case the species of the genus Speleophria can be considered Tethyan relicts.

From an ecological perspective, copepod assemblages in the cave of Vodeni Rat parallel those observed in many anchialine caves around the world composed of calanoids, halicyclopid cyclopoids, and speleophriid misophrioids. It is, indeed, widely recognized that anchialine caves host diverse crustacean assemblages with highly predictable taxonomic composition. Jaume et al. (2001) highlighted the recurrent composition of the communities in anchialine habitats as composed of atyid shrimps, thermosbaenaceans, hadziid amphipods, cirolanid isopods, remipeds, thaumatocypridid ostracods, and a vast array of copepods such as epacteriscid, pseudocyclopiid, and ridgewayiid calanoids, halicyclopid cyclopoids, speleophriid misophrioids, and superornatiremid harpacticoids. This observation suggests that the crustacean diversity of the cave of Vodeni Rat is probably underestimated and further sampling campaigns are needed to fully figure out the composition of the stygobitic communities. Moreover, additional samples will be needed for precise identification of the unique female individual of the ameirid harpacticoid Parapseudoleptomesochra sp. that was collected in Vodeni Rat.

\section{Amphipods}

Amphipods are among the most common and widespread crustaceans in Dinaric anchialine caves (Sket, 1999; Gottstein et al., 2012), where they are represented by three families, namely, Hadziidae Karaman, 1943, Salentinellidae Bousfield, 1977, and Niphargidae Bousfield, 1977. Hadziidae, although widespread along the whole Dalmatian coast (Sket, 1986; in Kornati Islands they were present in $42 \%$ of the caves: Gottstein et al., 2007), have so far not been recorded in Vodeni Rat, whereas the other two families are each represented in the cave by only one species.

The family Salentinellidae comprises small (up to $3 \mathrm{~mm}$ long) stygobitic amphipods of uncertain affinities inhabiting both freshwater and anchialine caves and interstitial waters, widely distributed in the Mediterranean basin and along the Dalmatian coast (Sket, 1969, 1986). Salentinella balcanica Karaman, 1953 (Fig. 3A) was described from a cave near Dubrovnik (as S. gracillima balcanica, S. gracillima Ruffo, 1947 being a species known from Apulia). It was subsequently synonymised with Salentinella angelieri Delamare Deboutteville \& Ruffo, 1952 from Corsica by Karaman (1979). However, a research in progress at the Université libre de Bruxelles on the phylogeny of the genus using molecular methods indicates that Dalmatian and Apulian populations are closely related each other, but show no affinities with the Corsican S. angelieri. For this reason, pending a nomenclatorial revision, in this study we maintain the binomial
Salentinella balcanica for Dalmatian populations. Although widely distributed along mainland Dalmatia (Sket, 1969, 1986), the species seems very rare in island caves, having been found so far only in an anchialine cave on the islet of Gangaro, Kornati archipelago (Karaman \& Sket, 1990). Unexpectedly, this species was the most common malacostracan collected in the cave of Vodeni Rat.

The family Niphargidae includes more than 400 described species, mainly stygobitic, distributed in the Western Palearctic. Niphargus hebereri Schellenberg, 1933 found in Vodeni Rat (Figs. 3A and 9A) is the most widespread crustacean species in anchialine caves along the Dalmatian coast (Gottstein et al., 2012); in Kornati islands a study found it in $83 \%$ of the sampled caves (Gottstein et al., 2007). Although on the nearby island of Hvar the most common species is Niphargus hvarensis Karaman, 1952, N. hebereri was recently collected in the island of Brač (Rađa et al., 2020).

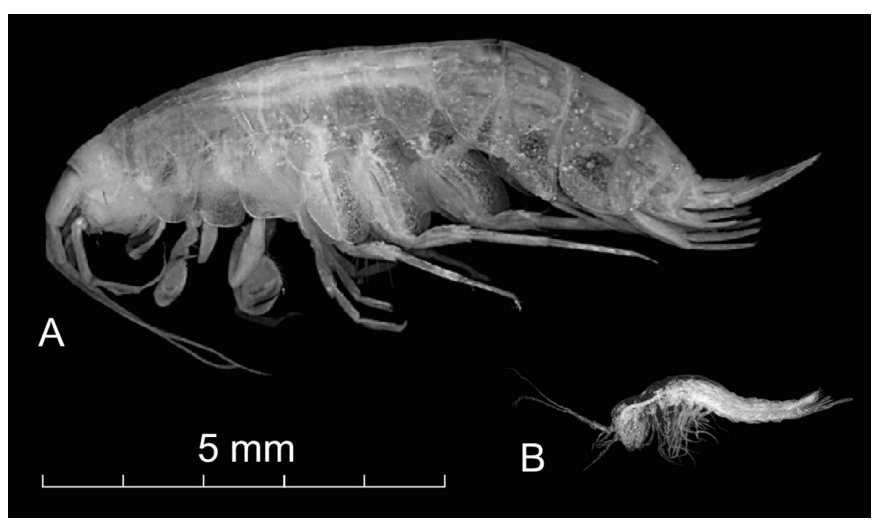

Fig. 9. A) The amphipod Niphargus hebereri, and B) the thermosbaenacean Tethysbaena halophila. Microphotographs taken under a stereomicroscope Leica M205C by B. Fiasca.

Described from a cave in the Istrian peninsula, it is found in fresh and brackish water caves along the coast as well as on islands; Sket (1966) hypothesized that it is a 'limnic immigrant' that tolerates mixohaline waters. This hypothesis was confirmed in a recent paper on the phylogeny of transadriatic Niphargidae (Delić et al., 2020). According to the latter study, during the Messinian Salinity Crisis, i.e., approximately 5.9$5.3 \mathrm{Ma}$, the ancestor of $N$. hebereri likely spread from the Apennine peninsula (where closely related species such as $N$. ictus Karaman, 1985 from the Frasassi cave complex in Marche region are present) and colonized the Adriatic islands as well as the mainland of the Dinaric karst. Subsequently, during the Pleistocene (2.5 Ma-11.7 ka), it presumably colonized again the Adriatic islands from the Dalmatian mainland. Its presence in the cave of Vodeni Rat was thus expected. However, the situation is more complex than it seems. As reported in Delič et al. (2020) and following an ongoing molecular revision, $N$. hebereri is composed of three distinct clades, which likely represent a complex of three cryptic species. The distribution of the three clades roughly follows the macro-geomorphological subdivision of the Adriatic coast of Croatia in North, Central, and South according to Bognar (1999). Our molecular analyses place the Vodeni Rat population clearly within the southern clade of N. hebereri. 


\section{Thermosbaenaceans}

Thermosbaenaceans are considered Tethyan relicts widely distributed in different groundwater habitats across the world (Wagner, 1994). With 35 species known so far, their distribution covers the shallow Mediterranean Sea or its coasts. Tethysbaena halophila Karaman, 1953 (Figs. 3A and 9B) has been frequently found in wells and caves of the Croatian mainland and islands (Sket, 1986, 1988; Wagner, 1994). This species tolerates low oxygen conditions, the presence of $\mathrm{H}_{2} \mathrm{~S}$, and a wide range of water salinity (from 0.5 to $30 \%$ o). Under polyhaline and mesohaline conditions (salinity from 18 to $30 \%$ and $5-18 \%$, respectively) the populations of $T$. halophila are quite dense whereas only a few individuals occur at lower salinity conditions (0.5-5\%o) (Sket, 1986). T. halophila frequently occurs with copepods of the genus Diacyclops, and amphipods of the genera Hadzia and Niphargus (Wagner, 1994). In the Cave of Vodeni Rat, a total of 4 specimens were collected, all in the upper freshwater layer of the cave (Figs 3A and 9B). Nevertheless, despite no specimens were found in the DEEP and BOTTOM samples with salinity of 38.7-39.0\% (Fig. 6), its presence in the brackish habitat cannot be ruled out since it was not sampled in this first survey of the Vodeni Rat Cave. Therefore, the presence of $T$. halophila in the cave of Vodeni Rat can be eventually verified by further sampling the transitional brackish water interval from about 5 to $9.5 \mathrm{~m}$ water depth and salinity ranging between 5 and 30\% (Table 2).

\section{DISCUSSION AND CONCLUSION}

The peculiarity of the Vodeni Rat Cave is that until the $4^{\text {th }}-7^{\text {th }}$ century $C E$ it was not an anchialine cave, but an ordinary dry karstic pit with freshwater of meteoric origin at the bottom, some $24 \mathrm{~m}$ below mean sea level. The cave was isolated from the surrounding phreatic environment by speleothemic calcite, which coats the inner walls of the cave, and fills fractures and joints crisscrossing the bedrock limestone. An U-Th date of $305 \mathrm{kyr}$ of speleothemic calcite taken from one of these fractures in the immediate vicinity of the cave entrance, suggests that the Cave of Vodeni Rat has been sealed since the late Middle Pleistocene. This suggests that limnicoid stygobitic crustaceans such as the amphipods Niphargus hebereri and Salentinella balcanica and the thermosbaenacean Tethysbaena halophila, which are found today in both freshwater and anchialine habitats along the eastern Adriatic coast, entered Vodeni Rat Cave prior to $305 \mathrm{ka}$, when this epigenic cave was located well above sea level in this subsiding part of the Dinaric foreland. Similarly, two specimens of the copepod species Diacyclops slovenicus, which is known only from freshwater habitats in caves throughout the inner Dinaric karst, were found in the upper freshwater layer of the cave, suggesting that it colonized the cave during the late Middle Pleistocene, and in any case not after the Early Medieval Period. A similar origin can be inferred from the abundant presence of copepod Halicyclops dalmatinus in the freshwater layer of Vodeni Rat
Cave. Before this study, this species was documented in brackish water bodies in Montenegro and Apulia, suggesting that these copepods, as well as the ostracod Pseudolimnocytere sp., may have entered the Vodeni Rat cave in the late Middle Pleistocene.

A different story is the one told by the copepod Speleophria mestrovi. This species was first described in the Supurina Cave in Vis Island by Kršinic (2008) in a highly saline habitat ( 37.0-38.0\%o). In Vodeni Rat, S. mestrovi was found abundant in the most saline part of the water column (38.8\%o) at about $14 \mathrm{~m}$ below mean sea level, and no specimens were caught in the freshwater part of the water column. This suggests that this species penetrated into the cave after the $4^{\text {th }}$ $7^{\text {th }}$ century CE when the cave became anchialine due to infiltration of highly saline waters probably from nearby tidally-influenced saturated cavities through newly open fractures and joints of the country rock limestone (Suárez-Morales et al., 2017).

The main question that remains to be answered is what happened between the mid $4^{\text {th }}$ and the mid $7^{\text {th }}$ centuries $\mathrm{CE}$ (i.e., the archeometric age span of amphora LR-1 found in the Vodeni Rat Cave) to the Momici and Soline Roman villas. The abandonment of these villas and the Vodeni Rat freshwater source may have something to do with the Late Antiquity Little Ice Age (LALIA 532-660 CE). This was a paroxysmal climatic crisis for humanity at a global scale in the troubled Early Medieval Period (i.e., the Dark Ages Cold Period or DACP, $4^{\text {th }}$ to $10^{\text {th }}$ century CE; Helama et al., 2017), which, in the middle of a long-term scenario of climate change, witnessed the fall of empires (e.g., the Roman Empire and the Eastern Turkic Empire; Fei et al., 2007; Buentgen et al., 2016), as well as migrations of entire populations from east to west and north to south in Europe and Asia (i.e., Vandals, Goths, Longobards, etc., with wars, conflicts, invasions, and destruction of preexisting social, political, and economical orders). More in particular, the LALIA period has been attributed to at least two exceptionally big volcanic events, which caused extreme yet different meteorological conditions in various parts of the world, such as droughts in mid and eastern Asia, torrential rains and floods in Japan, freezing cold in central Europe and northwestern Atlantic regions, cold and wet conditions in western Mediterranean regions, and "dry fogs" due to volcanogenic outgassing in various parts of the world (e.g., Stother \& Rampino, 1983; Ludlow et al., 2013). The years-lasting, widespread dry fogs produced by the megavolcanic events of 532 and $626 \mathrm{CE}$ would have set the conditions for acid rains, which may have head some effects on karstic regions by increasing carbonate dissolution on the surface as well as in fractures and joints like those surrounding the cave of Vodeni Rat until then sealed by cave calcite.

On the other hand, we should also consider the hypothesis by Evelpidou \& Pierazzoli (2017, and references therein), that a very strong earthquake occurred in the northern Adriatic in $361 \mathrm{CE}$ as part of an intense seismic sequence, which caused "... the coseismic subsidence of a known slightly submerged tidal notch that developed along over $200 \mathrm{~km}$ of the 
Croatian shoreline". This tidal notch was also reported in the Jerolim Islet of the Pakleni Archipelago by Montanari et al. (2019) and may represent a taleteller of a strong earthquake capable of fracturing the limestone surrounding the Vodeni Rat Cave, thus terminating its long isolation from the sea and the birth of an anchialine environment. Practically, if the Vodeni Rat LR-1 amphora turns out to be an early model compatible with the $4^{\text {th }}$ century $\mathrm{CE}$, than the hypothesis of Vodeni Rat becoming an anchialine cave after "tectonic perturbations", as Mesić (2006) originally proposed, becomes plausible.

In conclusion, our study of the stygobitic crustacean fauna in the Vodeni Rat neo-anchialine cave revealed the presence of freshwater species that were present in this cave since at least the late Middle Pleistocene before they were isolated from the rest of the surrounding hypogean karstic environment in a sort of speleothem-sealed time capsule. These species may have had a history different than that of conspecific populations, which adapted to living in anchialine caves of the Croatian karst that got invaded by seeping seawater in much earlier times. Verification of this hypothesis will require future comparative genetic analysis of all the species found in the Vodeni Rat Cave and those known to inhabit anchialine caves along the Croatian coasts as well as caves in the inner Dinaric karst.

\section{ACKNOWLEDGEMENTS}

We would like to thank the Association "Le Montagne di San Francesco" for financially supporting this research, archeologists Branko Kirigin and Marinko Petric for providing us background information about the history of Hvar and the archeology of the cave of Vodeni Rat, Paula Metallo for helping in the sampling campaign of June 2017, Jakša Dujmović for sailing us with his motorboat to Vodeni Rat during the expedition of May 2018, and Pjerino Šimunović for logistical support at his Dionis Restaurant in Soline. Last but not least, we would like to thank Serban M. Sarbu for his careful review of the original manuscript.

Authorship statement: AM designed and directed the study, participated in all sampling and field surveying campaigns, and wrote the paper with input from all authors. MM and SR participated in the sampling and field survey campaign of May 2018; J-FF, FS, and NC analyzed and determined the amphipods; DMG and $\mathrm{BF}$ analyzed all the bulk catches and determined the thermosbaenaceans and the copepods; TN analyzed and determined the ostracods; DM performed the $\mathrm{U}$-Th dating of a cave calcite sample.

\section{REFERENCES}

Begović, V., Ugarković, M., Schrunk, I., 2013. Roman villa in the Soline cove on the island of St. Clement near Hvar: Preliminary analysis of the architecture according to geophysical investigations and sondages. Prilozi Instituta za Arheologiju, 20/2012(1), 143-166.
Bishop, R.E., Humphreys, W.F., Cukrov, N., Žic, V., Boxshall, G.A., Cukrov, M., Iliffe, T.M., Kršinić, F., Moore, W.S., Pohlman, J.W., Sket, B., 2015. 'Anchialine' redefined as a subterranean estuary in a crevicular or cavernous geological setting. Journal of Crustacean Biology, 35(4), 511-514. https://doi.org/10.1163/1937240X-00002335

Bognar, A., 1999. Geomorfološka regionalizacija Hrvatske. Acta Geographica Croatica, 34, 7-29.

Bonacci, O., Pipan, T., Culver, D.C., 2009. A framework for karstecohydrology. Environmental Geology, 56, 891-900.

https://doi.org/10.1007/s00254-008-1189-0

Brancelj A., 1987. Cyclopoida and Calanoida (Crustacea, Copepoda) from the Postojna-Planina Cave System (Slovenia). Bioloski Vestnik, 35(1), 1-16.

Brancelj A., 1990. Favnisticni pregled ciklopoidov (Crustacea: Copepoda: Cyclopoida) v podzemeljskih habitatih $\mathrm{v}$ Bosni in Hercegovini. Bioloski Vestnik, 38(2), 15-26.

Brancelj A., 2001. Male of Moraria radovnae Brancelj, 1988 (Copepoda: Crustacea), and notes on endemic and rare copepod species from Slovenia and neighbouring countries. Hydrobiologia, 453, 513-524. https://doi.org/10.1023/A:1013139428099

Brlek, M., Korbar, T., Košir, A., Glumac, B., Grizelj, A., Otoničar, B., 2014. Discontinuity surfaces in Upper Cretaceous to Paleogene carbonates of central Dalmatia (Croatia). Glossifungites ichnofacies, biogenic calcretes and stratigraphic implications. Facies, 60, 467-487. https://doi.org/10.1007/s10347-013-0378-9

Büntgen, U., Myglan, V.S., Ljungqvist, F.C. McCormick, M., Di Cosmo, N., Sigl, M., Jungclaus, J., Wagner, S., Krusic, P.J., Esper, J., Kaplan, J.O., de Vaan, M.A.C., Luterbacher, J., Wacker, L., Tegel, W., Kyrdianov, A., 2016. Cooling and societal change during the Late Antique Little Ice Age from 536 to around $660 \mathrm{AD}$. Nature Geoscience, 9, 213-236. https://doi.org/10.1038/ngeo2652

Cvetkov, L., 1968. Un filet phréatobiologique. Bulletin de l'Institut de Zoologie et Musée. Académie Bulgare de la Science, 27, 215-218.

Cheng, H., Edwards, R.L., Shen, C.-C., Polyak, V.J., Asmerom, Y., Woodhead, J., Hellstrom, J., Wang, Y., Kong, X., Spötl, C., Wang, X., Calvin Alexander, E., 2013. Improvements in ${ }^{230} \mathrm{Th}$ dating, ${ }^{230} \mathrm{Th}$ and ${ }^{234} \mathrm{U}$ half-life values, and U-Th isotopic measurements by multi-collector inductively coupled plasma mass spectrometry. Earth and Planetary Science Letters, 371-372, 82-91. https://doi.org/10.1016/j.eps1.2013.04.006

Croizat, L., 1958. Panbiogeography. Volumes 1, 2a, and 2b. Published by the author, Caracas.

Culver, D.C., Sket, B., 2000. Hotspots of subterranean biodiversity in caves and wells. Journal of Cave and Karst Studies, 62(1), 11-17.

Danielopol, D.L., 1979. On the origin and the antiquity of the Pseudolimnocythere species (Ostracoda, Loxoconchidae). Biologia gallo-hellenica, 8, 99-107.

Danielopol, D.L., 1980. An essay to assess the age of the freshwater interstitial ostracods of Europe. Bijdragen tot de Dierkunde, 50(2), 243-291. https://doi.org/10.1163/26660644-05002001

Danielopol, D.L., Piller, W.E., Huber, T., 1991. Pseudolimnocythere hainburgensis n.sp. (Ostra coda, Loxoconchidae) aus dem Miozän (Badenium) des Wiener Beckens. Neues Jahrbuch für Geologie und Paläontologie, Monatshefte, Stuttgart, 8, 458-469. https://doi.org/10.1127/njgpm/1991/1991/458 
Delić, T., Stoch, F., Borko, S., Flot, J.-F., Fišer, C., 2020. How did subterranean amphipods cross the Adriatic Sea? Phylogenetic evidence for dispersal-vicariance interplay mediated by marine regression-transgression cycles. Journal of Biogeography, 47(9), 1875-1887. https://doi.org/10.1111/jbi.13875

Evelpidou, N., Pirazzoli, P.A., 2017. Did the Early Byzantine Tectonic Paroxysm (EBTP) also affect the Adriatic area? Geomorphology, 295, 827-830. https://doi.org/10.1016/j.geomorph.2017.08.026

Fei, J., Zhou, J. \& Hou, Y., 2007. Circa A.D. 626 volcanic eruption, climatic cooling, and the collapse of the Eastern Turkic Empire. Climatic Change, 81, 469-475. https://doi.org/10.1007/s10584-006-9199-y

Galassi, D.M.P., 2001. Groundwater copepods (Crustacea: Copepoda): diversity patterns over ecological and evolutionary scales. Hydrobiologia, 453, 227-253. https://doi.org/10.1023/A:1013100924948

Galassi, D.M.P., Dole-Olivier, M.-J., De Laurentiis, P., 1999. Phylogeny and biogeography of the genus Pseudectinosoma, and description of $P$. janineae sp. n. (Crustacea: Copepoda, Ectinosomatidae). Zoologica Scripta, 28(3-4), 289-303.

https://doi.org/10.1046/j.1463-6409.1999.00018.x

Gottstein, S., Ivković, M., Ternjej, I., Jalžić, B., Kerovec, M., 2007. Environmental features and crustacean community of anchihaline hypogean waters on the Kornati islands, Croatia. Marine Ecology, 28(1), 24-30. https://doi.org/10.1111/j.1439-0485.2007.00166.x

Gottstein, S., Kršinić, F., Ternjej, I., Cukrov, N., Kutlesa, P., Jalžić, B., 2012. Shedding light on crustacean species diversity in the anchihaline caves of Croatia. Natura Croatica, 21(1), 54-58. https://hrcak.srce.hr/87197

Helama, S., Jones, P.D., Briffa, K.R., 2017. Dark Ages Cold Period: A literature review and directions for future research. The Holocene, 17(10), 1600-1606. https://doi.org/10.1177/0959683617693898

Humphreys, W.F., 2004. Cape Range, Australia: Biospeleology. In: Gunn, J. (Ed.), Encyclopedia of caves and karst science. Taylor and Francis, London, p. 372-375.

Jaffey, A.H., Flynn, K.F., Glendenin, L.E., Bentley, W.C. Essling, A.M., 1971. Precision measurements of halflives and specific activities of ${ }^{235} \mathrm{U}$ and ${ }^{238} \mathrm{U}$. Physical Reviews C, 4(5), 1889-1906.

https://doi.org/10.1103/PhysRevC.4.1889

Jaume, D., Boxshall, G. A., Humphreys, W. F., 2001. New stygobiont copepods (Calanoida; Misophrioida) from Bundera Sinkhole, an anchialine cenote in northwestern Australia. Zoological Journal of the Linnean Society, 133 (1), 1-24.

https://doi.org/10.1111/j.1096-3642.2001.tb00620.x

Karanovic, I., Pesce, G.L., 2001. Ostracodes (Crustacea, Ostracoda) from underground waters of Puglia (southern Italy), with a redescription of Pseudolimnocythere hypogea Klie, 1938. Thalassia Salentina, 25, 11-39.

Karaman, G.S., 1979. The problem of Salentinella angelieri Del.-Deb. and Ruffo 1952 and its subspecies (Contribution to the Knowledge of the Amphipoda 109). Poljoprivreda i šumarstvo, Titograd, 25(4), 25-44.

Karaman, G.S., Sket, B., 1990. Two new Niphargus species (Amphipoda) from caves in Yugoslavia. International Journal of Speleology, 19, 51-66. https://doi.org/10.5038/1827-806X.19.1.5

Khodami, S., Mercado-Salas, N.F., Tang, D., Martinez Arbizu, P., 2019. Molecular evidence for the retention of the Thaumatopsyllidae in the order Cyclopoida (Copepoda) and establishment of four suborders and two families within the Cyclopoida. Molecular Phylogenetics and Evolution, 138, 43-52.

https://doi.org/10.1016/j.ympev.2019.05.019

Klie, W., 1938. Ostracoden aus unterirdischen Gewässern in Süditalien. Zoologischer Anzeiger, 123, 148-155.

Korbar, T., 2009. Orogenic evolution of the External Dinarides in the NE Adriatic region: A model constrained by tectonostratigraphy of Upper Cretaceous to Paleogene carbonates. Earth-Science Reviews, 96, 296312. https://doi.org/10.1016/j.earscirev.2009.07.004 Korbar, T., Cvetko Tešović, B., Radovanović, I., Krizmanić, K., Steuber, T., Skelton, P.W., 2010. Campanian Pseudosabinia from the Pučišca Formation on the Island of Hvar (Adriatic Sea Croatia). Turkish Journal of Earth Sciences, 19, 721-731.

Korbar, T, Montanari, A., Premec Fuček, V., Fuček, L., Coccioni, R., McDonald, I, Claeys, Ph., Schulz, T, Koeberl, Ch., 2015. Potential Cretaceous-Paleogene boundary tsunami deposit in the intra-Tethyan Adriatic carbonate platform section of Hvar (Croatia). Geological Society of America Bulletin, 127, 16661680. https://doi.org/10.1130/B31084.1

Kršinic, F., 2008. Description of Speleophria mestrovi sp. nov., a new copepod (Misophrioida) from an anchialine cave in the Adriatic Sea. Marine Biology Research, 4(4), 304-312.

https://doi.org/10.1080/17451000801930072

Ludlow, F., Stine, A.R., Leahy, Paul, Murphy, E., Mayewski, P.A. Taylor, D., Killen, J., Baillie, M.G.L., Hennessy, M., Kiely, G., 2013. Medieval Irish chronicles reveal persistent volcanic forcing of severe winter cold events, 431-1649 CE. Environmental Research Letters, 8, 024035. https://doi.org/10.1088/1748-9326/8/2/024035

Mesić, J., 2006. L'esplorazione archeologica a scopo protettivo della grotta di Vodeni Rat. In: Radić Rossi, I. (Ed.), Archeologia subacquea in Croazia. Studi e ricerche, Marsilio, Venezia, p. 91-100.

Montanari, A., Bice, D.M., Jull, A.J.T., Kudryavtsev, A.B., Macalady, J.L., Schaperdoth, I., Sharp, W.D., Shimabukuro, D., Schopf, W.J., Vucetić, V., 2019. Pelagosite revisited: The origin and significance of a laminated aragonitic encrustation of Mediterranean supralittoral rocks. In: Koeberl, C., Bice, D.M., (Eds.), 250 million years of Earth history in Central Italy: Celebrating 25 years of the Geological Observatory of Coldigioco. Geological Society of America Special Paper 542, 501-532. https://doi.org/10.1130/2019.2542(28)

Montanari, A., Adamek, A., Curatolo, A., Ferretti, M.P., Mainiero, M., Mariani, S., McGee, D., Pignocchi, G., Recanatini, S., 2020. An Epigravettian hypogeal site in the Grotta del Fiume Cave at Frasassi (northeastern Apennines, Italy): Environmental and geochronologic assessments. International Journal of Speleology, 49(2), 87-105. https://doi.org/10.5038/1827-806X.49.2.2324

Oštrić, N., Jelaska, V., Fuček, L., Prtoljan, B., Korolija, B., Gušić, I., Marinčić, S., Šparica, M., Korbar, T., Husinec, A., 2015. Basic geological map of the Republic of Croatia, Sheet "The Island of Hvar": Zagreb, Croatia, Croatian Geological Survey, Department of Geology, scale 1:50,000.

Pandža, M., Milović, M. 2015. Flora of the islets near Pakoštane (Dalmatia, Croatia). Natura Croatica, 24(1), 19-35. https://doi.org/10.20302/NC.2015.24.2

Pavelić, D., Kovačić, M., Vlahović, I., Wacha, L., 2011. Pleistocene calcareous aeolian-alluvial deposition in a steep relief karstic coastal belt (island of Hvar, eastern Adriatic, Croatia). Sedimentary Geology, 239, 64-79. https://doi.org/10.1016/j.sedgeo.2011.05.005 
Pavelić, D., Kovačić, M., Vlahović, I., Mandic, O., Marković, F., Wacha, L., 2014. Topography controlling the wind regime on the karstic coast: Late Pleistocene coastal calcareous sands of eastern mid-Adriatic, Croatia. Facies, 60, 843-863. https: / / doi.org/10.1007/s 10347-014-0411-7

Pesce, G.L., Maggi D., Tetè P., 1984. Stato attuale delle conoscenze sui Ciclopidi delle acque sotterranee della Puglia (Crustacea: Copepoda). Carsia Apula, 1, 71-92.

Peterson, D., Finger, K., Iepure, S., Mariani, S., Montanari, A., Namiotko, T., 2012. Reconnaissance of ostracodes in the Frasassi caves and adjacent sulfidic spring and Sentino River in the northeastern Apennines of Italy. Journal of Cave and Karst Studies, 75, 11-27. https://doi.org/10.4311/2011PA0230

Petkovski, T.K., 1954. Beitrag zur Kenntnis der Jugoslavischen Cyclopiden. Acta Musei Macedonici Scientiarum Naturalium, Skopje, 2(1), 1-31.

Petkovski, T.K., 1955. IV Beitrag zur Kenntniss der Copepoden. Acta Musei Macedonici Scientiarum Naturalium, Skopje, 3(3), 71-104.

Petkovski, T.K., 1984. Neue und seltene Copepoden (Crustacea) aus Jugoslawien. Acta Musei Macedonici Scientiarum Naturalium, Skopje, 17(6), 135-164.

Petrić, M., 2017. Zaštitno arheološko istraživanje jame na Vodenom ratu. Prilozi povijesti otoka Hvara, 13(1), $1-11$.

Piéri, V., Martens, K., Meisch, C., Rossetti, G., 2015. An annotated list of recent non-marine ostracods (Ostracoda: Crustacea) from Italy. Zootaxa, 3919(2), 271-305. https://doi.org/10.11646/zootaxa.3919.2.3

Piéri, D., 2005. Les centres de production d'amphores en Méditerranée orientale durant l'Antiquité tardive: quelques remarques. LRCW 2. Late Roman Coarse Wares, Cooking Wares and Amphoras in the Mediterranean: Archaeology and archaeometry, May 2005, Aix-en-Provence, Marseille, Arles, p. 611-625

Rađa, B., Bonacci, O., Rađa, T., Šantić, M., 2020. The water and biology on a small Karstic island: the Island of Brač (Croatia) as one example. Environmental Earth Sciences, 79, 116. https://doi.org/10.1007/s12665-020-8844-5

Radić Rossi, I., Cukrov, N., 2017. Archaeological potential of anchialine caves in Croatia. In: Bailey, G.N., Harff, J., Sakellariou, D. (Eds.), Under the sea: Archaeology and palaeolandscapes of the continental shelf. Coastal Research Library, 20, Springer, Cham, p. 255-266. https://doi.org/10.1007/978-3-319-53160-1_17

Reynolds, P., 2005. Levantine amphoras from Cilicia to Gaza: a typology and analysis of regional production trends from the $1^{\text {st }}$ to $7^{\text {th }}$ centuries. In: Gurt, J.M., Buxeda, J., Cau, M.A. (Eds), LRCW1. Late Roman coarsewares, cooking wares and amphoras in the Mediterranean: archaeology and archaeometry. BAR International Series, Oxford, 1350, p. 563-611.

Schellenberg, A., 1933. Weitere deutsche und ausländische Niphargiden. Zoologischer Anzeiger, 102, 22-33.

Sket, B., 1966. The ecology of anchihaline caves. Trends in Ecology \& Evolution, 11(5), 221-225. https://doi.org/10.1016/0169-5347(96)20031-X

Sket, B., 1969. Über die Verbreitung einiger Malacostraca (Hadzia, Salentinella, Neogammarus, Jaera) längs der Jugoslawischen Adria-Küste. Bulletin Scientifique, Conseil des Académies des sciences et des arts de la RSF de Yougoslavie, section A: Sciences naturelles, techniques et médicales, 14(5-6), 147-148.

Sket, B., 1986. Ecology of the mixohaline hypogean fauna along the Yugoslav coasts. Stygologia, 2, 317-338.

Sket, B., 1988. Zoogeography of the freshwater and brackish Crustacea in the Kvarner-Velebit islands (NW Adriatic, Yugoslavia). Bioloski Vestnik, 36, 63-76.

Stothers, R.B., Rampino, M.R., 1983. Historic volcanism, European dry fogs, and Greenland acid precipitation, $1500 \mathrm{BC}$ to AD 1500. Science, 222, 411-413. https://doi.org/10.1126/science.222.4622.411

Suárez-Morales, E., Cervantes-Martínez, A., GutiérrezAguirre, M.A., Iliffe, T.M., 2017. A new Speleophria (Copepoda, Misophrioida) from an anchialine cave of the Yucatán Peninsula with comments on the biogeography of the genus. Bulletin of Marine Science, 93(3), 863878. https://doi.org/10.5343/bms.2017.1012

Surić, M., Korbar, T., Juračić, M., 2014. Tectonic constraints on the late Pleistocene-Holocene relative sea-level change along the north-eastern Adriatic coast (Croatia). Geomorphology, 220, 93-103. https://doi.org/10.1016/j.geomorph.2014.06.001

Surić, M., Juračić, M., 2010. Late Pleistocene-Holocene environmental changes - records from submerged speleothems along the Eastern Adriatic coast (Croatia). Geologia Croatica, 63 (2), 155-169. https://doi.org/10.4154/gc.2010.13

Wacha, L., Montanari, A., Lomax, J., Fiebig, M., Lüthgens, C., Korbar, T., Koeberl, C., 2019. Last Glacial Maximum giant sand dunes on the island of Vis, Croatia. In: Koeberl, C., Bice, D.M. (Eds.), 250 million years of Earth history in Central Italy: Celebrating 25 years of the Geological Observatory of Coldigioco. Geological Society of America Special Paper 542, 459-470. https://doi.org/10.1130/2019.2542(26)

Wagner, H.P., 1994. A monographic review of the Thermosbaenacea (Crustacea: Peracarida) A study on their morphology, taxonomy, phylogeny and biogeography. Zoologische Verhandelingen Leiden, 291, 1-338. 